\title{
Review
}

\section{Effect of vitamin D on graft-versus-host disease}

\author{
Alfonso Rodríguez-Gil ${ }^{1}$, Estrella Carrillo ${ }^{2}$, Cristina Marrero-Cepeda ${ }^{2}$, Guillermo Rodriguez ${ }^{2}$, Jose A Pérez-Simón ${ }^{1,2^{*}}$ \\ 1 Instituto de Biomedicina de Sevilla (IBIS / CISC), Universidad de Sevilla; \\ 2 Department of Hematology, University Hospital Virgen del Rocio, Instituto de Biomedicina de Sevilla (IBIS \\ / CISC) \\ * Correspondence: Jose A Perez-Simon. Head of Department of Hematology. University Hospital Virgen del \\ Rocio. e.mail: josea.perez.simon.sspa@juntadeandalucia.es.
}

\begin{abstract}
The different cell subsets of the immune system express vitamin D receptor (VDR). Through VDR, vitamin D exerts different functions which influences on immune responses, as previously shown in different preclinical models. Based on this background, retrospective studies have explored the impact of vitamin D levels on the outcome of patients undergoing allogeneic hematopoietic stem cell transplantation, showing that vitamin $\mathrm{D}$ deficiency is related to an increased risk of complications, especially graft-versus-host disease. These results have been confirmed in a prospective cohorts trial, although further studies are required to confirm this data. In addition, the role of vitamin $\mathrm{D}$ on the treatment of hematologic malignancies has also been explored. Considering this dual effect both on the immune system as well as on tumor cells in patients with hematologic malignancies, vitamin D might be useful in this setting both to decrease graft-versus-host disease and relapse rates.
\end{abstract}

Keywords: vitamin D ; calcifediol ; cailcitriol ; graft-versus-host disease ; vitamin D receptor (VDR)

\section{INTRODUCTION:}

Despite its name, vitamin D is in fact a secosteroid hormone [1]. Currently there is a concern on vitamin D levels in the population at a worldwide level, with a prevalence of severe vitamin D deficiency (defined as 25-OH-Vitamin D serum levels lower than 30 $\mathrm{nmol} / \mathrm{L}$ ) ranging from $2.9 \%$ in the United States, $7.4 \%$ in Canada or $13 \%$ in Europe to more than $20 \%$ in India, Pakistan and Afghanistan [2-5]. Several studies have addressed the intervention on this deficiency in vitamin $\mathrm{D}$, although clinical trials for its supplementation have not reached satisfactory results (reviewed in Amrein et al. [6]). The incidence of vitamin D deficiency is even higher among patients undergoing allogeneic hematopoietic stem cell transplantation, due to long term hospitalizations or liver or renal toxicities, among other reasons.

\section{CHEMICAL STRUCTURE, SYNTHESIS AND METABOLISM OF VITAMIN D:}

Vitamin D chemical structure, synthesis and metabolism has been reviewed in [7]. In brief, it was initially discovered in 1919 by Edward Mellanby [8] as a micronutrient able to prevent rickets in dogs. Vitamin D is the common name assigned to a family of members, but usually refers to the precursor form Vitamin $\mathrm{D}_{3}$ or cholecalciferol. Vitamin $\mathrm{D}_{3}$ is, produced in the skin by the photolytic effect of the UV light on 7-dehydro-cholesterol to produce pre-vitamin $\mathrm{D}_{3}$ and the subsequent thermal isomerization to vitamin $\mathrm{D}_{3}$. Vitamin $\mathrm{D}$ can also be obtained in the diet either as vitamin $\mathrm{D}_{3}$, of animal origin and vitamin $\mathrm{D}_{2}$ 
(ergocalciferol), of vegetal and fungal origin. Vitamin $\mathrm{D}_{3}$ is further processed to 25-hydroxyvitamin $\mathrm{D}_{3}$ in the liver, by the enzyme vitamin $\mathrm{D}_{3}-25$-hydroxilase, codified by the gene CYP2R1.

25-hydroxyvitamin $\mathrm{D}_{3}$ is the main circulating form and the clinically used marker to assess vitamin $\mathrm{D}_{3}$ levels. 25-hydroxyvitamin $\mathrm{D}_{3}$ is further processed to 1,25-dihydroxyvitamin $D_{3}$, which is the active form [9-11], by the vitamin D-1 $\alpha$-hydroxylase, encoded by the gene CYP27B1 [12,13]. This step takes place mainly in the kidney, but many other tissues also express this gene, including several immune populations. Finally, vitamin $\mathrm{D}_{3}$ is deactivated by the enzyme vitamin D 24-hydroxylase, which is expressed in almost all cells [14], producing 24,25 dihydroxyvitamin $\mathrm{D}_{3}$, which is further processed and excreted thought the bile (figure 1).
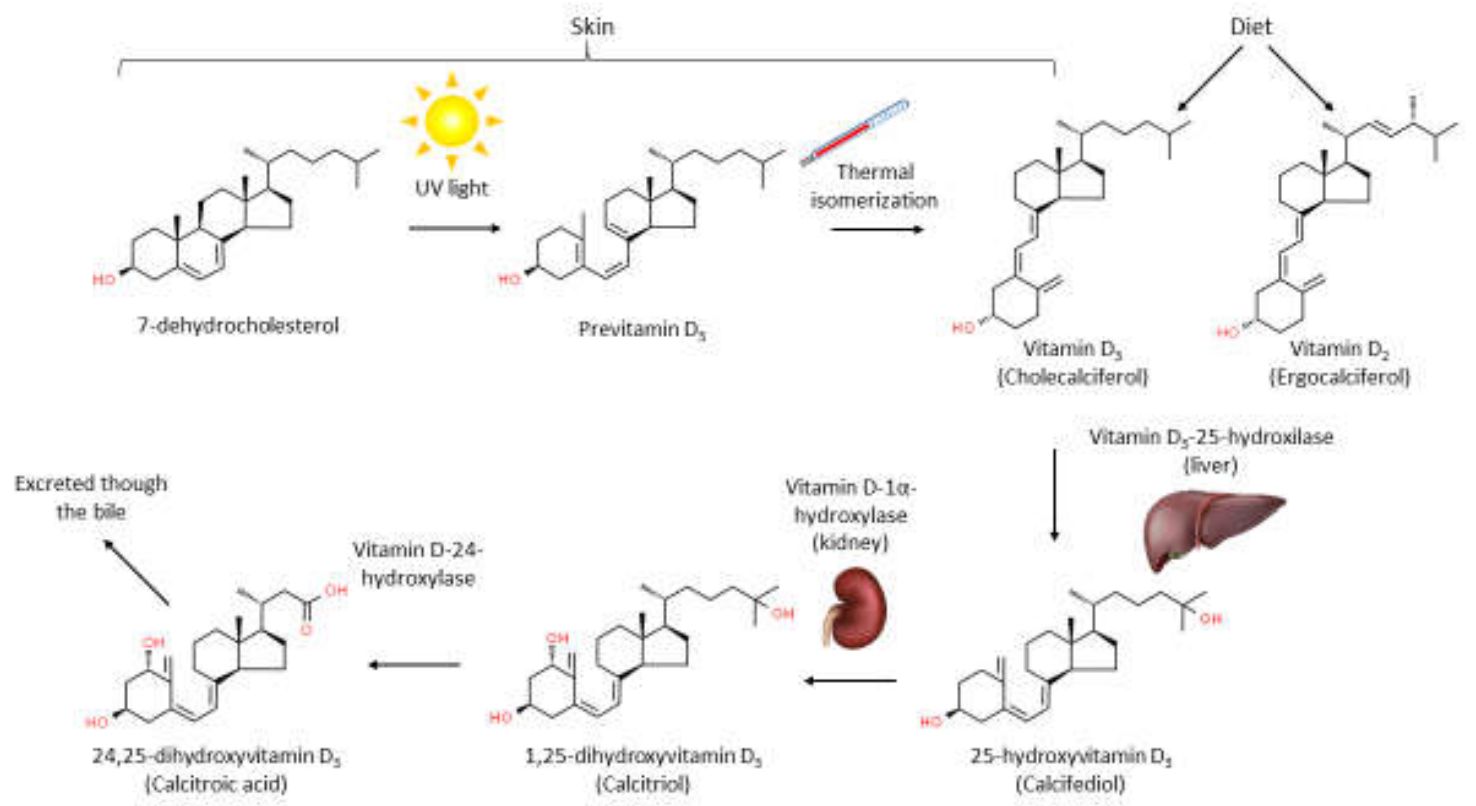

Figure 1. Metabolism of Vitamin D

Vitamin D exerts its function mainly through the binding to vitamin D receptor (VDR), which belongs to the family of the steroid nuclear receptors [15]. VDR dimerizes with the Retinoic $X$ receptor (RXR) upon vitamin D binding [16,17], and binds to DNA in the so called vitamin D response elements (VDRE) [18]. Interestingly, VDR also have vitamin D independent actions [19]. This is the case of the role of VDR in hair follicle cycling [20] or in skin cancer development [21].

Several naturally occurring polymorphisms have been described in the VDR gene [22-26], using restriction fragment length polymorphisms (RFLP). Of special interest is the FokI polymorphism, located in the second exon of the VDR mRNA. This polymorphism generates an alternative star codon which renders a protein three amino acids shorter (424 vs 427 aas), with higher transcriptional activity [26]. The BsmI, ApaI and TaqI sites are also extensively studied. These three polymorphisms map in the last intron of the gene, close to the 3' UTR of the VDR mRNA, and they are genetically linked. VDR polymorphism have been associated to defects in bone metabolism (see [27] and additional references therein). The FokI polymorphism has also been described to have impact on the immune system [28] 


\section{CLASSICAL AND NON-CLASSICAL EFFECTS OF VITAMIN D.}

Beyond the classical effects on calcium and phosphate homeostasis and bone formation [1], the vitamin D has also non-classic functions [29] in the regulation of hormone synthesis and secretion, including the parathyroid hormone (PHT), the fibroblast growth factor 23 (FGF-23) or insulin, in cell proliferation in the skin, in cancer and in the immune system

\section{EFFECTS ON THE IMMUNE SYSTEM}

Already in the decade of 1980, it was described that the vitamin D has multiple direct effects on the immune system function [30-36]. Even before, the first link between immune system and vitamin D comes from the observation that cod liver oil could be used for the treatment of tuberculosis $[37,38]$. Since then, many studies have elucidated the molecular mechanisms by which vitamin $\mathrm{D}$ affects immune cells. $\mathrm{B}$ and $\mathrm{T}$ lymphocytes, monocyte/macrophages, dendritic cells(DCs) and natural killer (NK) cells express VDR $[30,35,39,40]$, and most immune populations also express the $1 \alpha$-hydroxylase $[39,41-43]$.

Effect on innate immune cells.

Monocytes and Macrophages: Both monocytes and macrophages express the VDR and the $1 \alpha$-hydroxylase [44]. In both cases, their expression is induced upon the stimulation of toll-like receptors (TLR) 2/1 by pathogen associated molecular patterns (PAMPs) [45] and interferon $\gamma($ IFN- $\gamma$ ) [41]. Vitamin D induces the expression of antimicrobial proteins such as cathelicidin and $\beta$-defensin-2 [46,47], playing an important role in the first response to microbial infections On the other hand, vitamin D skews the polarization of monocytes to a less pro-inflammatory phenotype, altering the cytokine secretion profile by changing the MAPK1 signaling [48,49]. Additionally, vitamin D impairs the maturation of monocytes to dendritic cells [50], while favoring the phagocytic capacity of macrophages though the induction of complement receptors [51].

Dendritic cells: DCs form a complex system of different subsets that play a central role in the activation of the adaptive immune response through their antigen presenting capacity to T cells [52]. The effect of vitamin D in DCs has been reviewed by Bscheider and Butcher [53]. Vitamin D inhibits the differentiation, maturation, activation and survival of dendritic cells $[54,55]$, which lead to a reduced activation of T cells. These tolerogenic state is driven by metabolic changes in the vitamin D treated DCs [56]. DCs activated in the presence of vitamin D also showed altered trafficking properties [57]. Finally, DCs have been proposed to provide T cells with 25-hydroxy-vitain D3 in a paracrine fashion, inducing the expression of CCR10 and altering the migratory properties of these T cells [58]

Neutrophils: Neutrophils represent the mayor population of the innate immune compartment Although they express VDR, and several genes modify their expression upon vitamin D treatment [59], the effect on their functionality is controversial. Neutrophils exert their function using three different strategies: phagocytosis, degranulation and formation of the so called neutrophil extracellular traps (NETs) [60]. NETs are web like structures formed by proteins and DNA excreted by the neutrophils upon stimulation, which are able to trap, neutralize and kill bacteria, but can also contribute to autoimmunity [61]. Vitamin D has been described to prevent the endothelial damage induced by NETS in Systemic Lupus Erythematosus (SLE) [62], but in the other hand, it has also been shown to induce the formation of NETs in in vitro cultures [62].

NK cells: The effect of vitamin D on NK cells has not been exhaustively investigated. In vitro studies have shown that vitamin D impairs NK differentiation from HSCs [63], 
favoring monocyte production. Mature NK cells however were not affected in cytotoxicity or IFN- $\gamma$ secretion.

\section{Effect on adaptative immunity}

T lymphocytes: T cells express VDR, and this expression is upregulated upon activation [64]. Among T cells, Th1 and Th17 CD4 T cells show the higher expression [65]. VDR knock out mice showed no significant changes in myeloid or lymphoid populations, but a reduced Th1 polarization with downregulated IFN- $\gamma$ secretion and increased IL4 production was observed upon stimulation [66]. CD4 and CD8 $\alpha \alpha$ T cells from VDR KO mice show a reduced homing capacity to the gut, due to reduced CCR9 expression levels [67]. Human T lymphocytes treated with vitamin D also show a reduced Th1 response $[65,68]$. TCR signaling is also affected by vitamin D. Phospholipase C $\gamma-1$ (PLC $\gamma-1)$ is a key signaling enzyme downstream of the TCR activation cascade, whose expression is controlled by VDR in human T cells [69]. In the presence of a vitamin D antagonist, the expression of PLC $\gamma-1$ is downregulated, and therefore TCR signal is impaired. Many studies have shown the influence of vitamin D in Tregs (reviewed in [70]). Treatment with vitamin D in induces immunotolerance by increasing Treg numbers in a DC dependent manner $[71,72]$ through the favoring of a tolerogenic phenotype of DCs. Vitamin D is able also to influence both IL10+ and Foxp3+ Tregs directly, promoting their expansion [73]. As mentioned previously, vitamin D enhanced the VDR signaling through the upregulation of PLC $\gamma$-1. In Tregs, the activation of this axis leads to the expression of the anti-inflammatory cytokine TGF- $\beta 1$ [74], increasing their regulatory properties.

B cells: As in the case of T cells, B cells express low levels of VDR in resting state, and upregulate it upon activation [75]. In vitro activated B cells showed decreased plasma cells differentiation and Ig secretion when cultured under vitamin D supplementation [31,7577]. The targeting of the VDR with an agonist leads to inhibition of B cell dependent allergic responses in a murine model of type I allergy [78]. Additionally, vitamin D induces the production of IL10 up to 3 fold [79], suggesting a role in the development of regulatory $B$ cells [80]. However, these effects have not been observed in vivo in human samples [81], and therefore the actual role of vitamin D in B cells in vivo remain to be clarified.

Given the broad effects of vitamin D in immune cells, the consequences of vitamin D deficiency on inflammatory and autoimmune diseases has been extensively investigated (reviewed in Ao et al. and Hayes et al. [65,82]). In the past two years, the role of vitamin $\mathrm{D}$ in the immune response to Covid19 has also attracted great interest (reviewed in Ghelani et al. [83]). The importance of vitamin D in stem cell transplantation will be discussed in the following section, and has been reviewed by Soto et al. [84] and Hong et al. [85]. Vitamin D impact on leukemia and hematopoiesis [86], and in cancer in general [87] has also been recently reviewed

The effects of vitamin D in immune cells is summarized in figure 2 


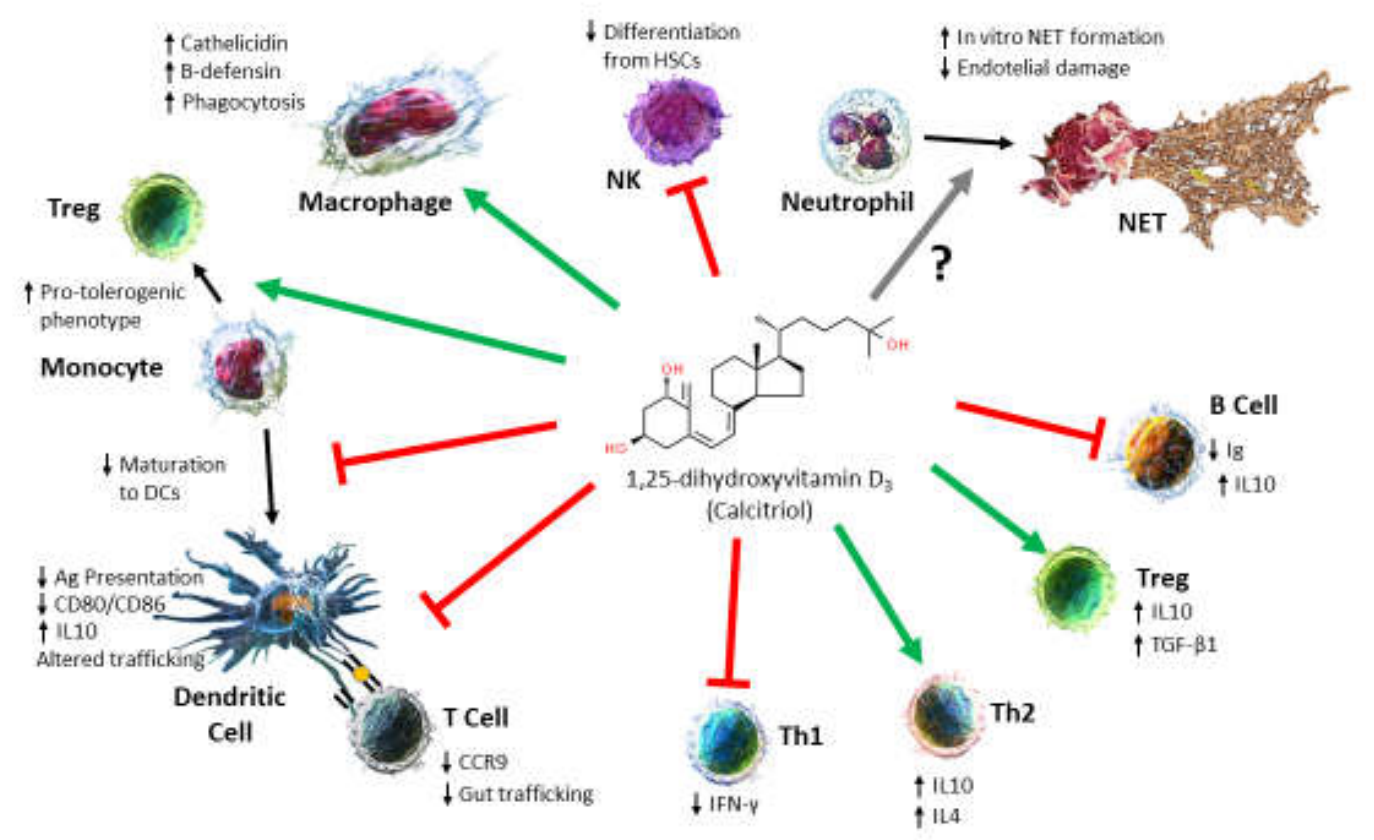

Figure 2. Summary of vitamin D effects on immune cells

Preclinical models of vitamin $D$ in immune diseases and solid organ transplantation

Several preclinical mouse models evaluating the impact of vitamin D in immune diseases have been developed, including solid organ transplant, experimental autoimmune encephalomyelitis (EAE), autoimmune diabetes, ulcerative colitis, systemic lupus erythematosus (SLE), autoimmune thyroiditis, collagen induced arthritis, and graft versus host disease (GvHD):

Solid organ transplant models: Adorini et al. showed in 2003 that vitamin D, alone or in combination with mophetil mycophenolate was able to prevent rejection in a heart transplant model [88], through the increase of Treg numbers induced by tolerogenic DCs. More recently, Xi et al have used a combination of anti CD40L antibody and vitamin D to prevent memory $\mathrm{T}$ cell mediated rejection also in heart transplant [89]. The use of vitamin $\mathrm{D}$ in mouse models of pancreatic islet transplantation has been reviewed by Infante et al [90]

Autoimmune diabetes: Autoimmune diabetes mouse models, based on the non obese diabetes (NOD) strain have also been used to study the role of vitamin D in diabetes development, not only in islet transplantation. Vitamin D reduces immune response to pancreatic islands by increasing Tregs [91] and lowering pro-inflammatory cytokines production [92]. Interestingly, VDR knock out NOD mice presented unaltered presentation of diabetes compared to VDR+/+ mice [93].

Experimental autoimmune encephalomyelitis: EAE is a preclinical model for multiple sclerosis. Vitamin D has been shown to reduce EAE in a IL10 signaling dependent manner [94], by altering the chemokine secretion and monocyte trafficking [95] Rag1 dependent cells are essential for this response [96], however CD8+ cells are not necessary [97]. Conditional deletion of VDR in T cells abolished the beneficial effect of vitamin D on EAE [98]

Systemic lupus erythematosus: The mouse strain MLR/1 is a model of spontaneous SLE syndrome. Treatment of these strain with vitamin D reduces the appearance of some manifestation of the disease [99]. In another model of SLE, pristine-induced lupus [100], vitamin D alleviates arthritis but does not reduce renal injury [101] 
Ulcerative colitis: Two widely used mouse models of ulcerative colitis are IL10 KO mice and dextran sodium sulfate (DSS) induced colitis. In the first case, ulcerative colitis is developed spontaneously in a TNF- $\alpha$ signaling dependent manner. The severity is lower when high calcium or 1-25 di-hydroxy-vitamin D3 are included in the diet, while. IL10 VDR double KO develop a fulminating form of the disease [102]. In the case of DSS induced colitis, the deletion of VDR also renders a hypersensitivity to the agent [103], and vitamin D deficiency leads to impaired gut antimicrobial response and increased colitis predisposition [104].

Stem cell transplantation and GVDH: Despite the abundance of animal models in GvHD, to date the published reports on the effect of vitamin D on GvHD animal models are scarce. In 2001, Pakkala et al. reported that the vitamin D analog MC1288 prevented acute GvHD in rats [105]. More recently, Taylor et al. described that vitamin D can alleviate GvHD in allogeneic hematopoietic stem cell transplantation recipients. Using VDR KO donors the effect was retained, indicating that the vitamin D effect was recipient, and not donor, dependent [106].

\section{VITAMIN D IN THE CLINICAL SETTING:}

\section{Vitamin D compounds available in the clinical setting}

The natural compounds ergocalciferol (vitamin $\mathrm{D}_{2}$ ), cholecalciferol (vitamin $\mathrm{D}_{3}$ ), calcifediol (25-hydroxyvitamin $\mathrm{D}_{3}$ ) and calcitriol (1,25-dihydroxyvitamin $\left.\mathrm{D}_{3}\right)$ are available for use in clinics as supplements. Other synthetic products can be employed as so-called "analogs".

A meta-analysis of randomized controlled trials that have directly compared the effects of ergocalciferol and cholecalciferol confirms that cholecalciferol increases serum 25hydroxyvitamin $\mathrm{D}$ faster than does ergocalciferol, may be due to the affinity for the VDR [107]. Cholecalciferol and calcifediol are commonly administered for vitamin D deficiency, although calcifediol is faster in action, more potent and has a shorter half-life as compared to the prohormones [108].

Chronic kidney disease (CKD) generate hyperparathyroidism, osteomalacia and adynamic bone disease. In CKD patients, calcifediol normalizes vitamin D levels and decreases high PTH concentration

Calcitriol is preferably used in case of secondary hyperparathyroidism in patients with CKD and in patients with hypocalcemia and normal renal function as it increases intestinal calcium absorption [109]. In patients with CKD the use of calcitriol has a risk of hypercalcemia and vascular calcification.

In this context several synthetic vitamin $D$ analogs can be used: paricalcitol $(1,25 \mathrm{di}-$ hydroergocalciferol), doxercalciferol (1-alpha-ergocalciferol), alfacalcidol (1-alpha-hydroxyvitamin $\mathrm{D}_{3}$ ) or maxacalcitol (22-oxacalcitriol) [110]. All of them can be used in the treatment of secondary hyperparathyroidism in CKD patients although paricalcitol and alfacalcidol might be related to a lower risk of hypercalcemia and hypophosphatemia [111].

The recommended doses depend on whether the subject has vitamin D deficiency or not. The diagnosis of vitamin $\mathrm{D}$ deficiency is established by low serum concentrations of 25-hydroxyvitamin D. Reference values are controversial and differ between populations due to diet intake, age, geography, sun exposure, etc. The Institute of Medicine (IOM) committee [112] propose a reference value for healthy population above $20 \mathrm{ng} / \mathrm{ml}$ in serum while the International Osteoporosis Foundation (IOF) define it above 30ng/ml [113]. A vitamin D deficiency staging has been proposed [114,115] in which vitamin D insufficiency is defined when serum 25-hydroxyvitamin D levels are below $50 \mathrm{nmol} /$ liter (20 $\mathrm{ng} / \mathrm{ml})$. This is associated with mild elevations of serum iPTH and biochemical markers 
of bone turnover. Moderate vitamin D deficiency (25-hydroxyvitamin D serum levels are below $25 \mathrm{nmol} /$ liter or $10 \mathrm{ng} / \mathrm{ml}$ ) is associated with serum iPTH concentration moderately increased and high bone turnover. In severe vitamin D deficiency (serum 25-hydroxyvitamin D levels lower than $12.5 \mathrm{nmol} /$ liter or $5 \mathrm{ng} / \mathrm{ml}$ ), patients may be at risk of rickets and/or osteomalacia. Also, a maximum reference value of $60-70 \mathrm{ng} / \mathrm{ml}$ has been proposed [116].

In the healthy population, recommended doses of cholecalciferol are 400 International Unit (IU)/day for infants (1 IU equal to $0.025 \mathrm{mcg}$ ), $600 \mathrm{IU} /$ day for children and adults until the age of 70 (including pregnant and lactating women) and $800 \mathrm{IU} /$ day above this age [112]. The American Geriatrics Society (AGS) and the National Osteoporosis Foundation (NOF) recommends 800 UI to $1000 \mathrm{UI}$ daily to reduce the risk of fractures and falls in people $\geq 65$ years.

In patients with vitamin $\mathrm{D}$ deficiency higher doses are needed. To find the proper dose, a deficiency calculation should be considered. For every 100 units $(2.5 \mathrm{mcg})$ of added vitamin D3, serum 25-hydroxyvitamin D concentrations will increase by 0.7 to $1.0 \mathrm{ng} / \mathrm{mL}$ ( 1.75 to $2.5 \mathrm{nmol} / \mathrm{L}$ ) [117]. In case of severe deficiency, 4,000 to 6,000 IU daily could be given for the first 4-6 weeks, followed by dose adjustment in accordance with the biochemical response monitored at 3-months intervals, to achieve the recommended maintenance dose and then continue monitoring at 6-month intervals [118]. Different dosage modalities have been tested with overlapping results. Therefore, vitamin $\mathrm{D}$ can be prescribed daily, once a week or once a month as it has a half-life of 2-3 weeks and is released slowly from the storage in the fat [119].

\section{VITAMIN D AND HEMATOLOGIC MALIGNANCIES}

The potential antitumor effect of vitamin D and the low serum levels of 25-hydroxyvitamin $\mathrm{D}$ reported in many neoplasms have led to consider a potential role of vitamin D in the treatment and prevention of cancer. Nevertheless, in a randomized trial controlled-placebo, carried out in more than 25000 subjects, supplementation with cholecalciferol 2,000UI daily did not result in a lower incidence of invasive cancer than placebo [120].

The ability of Vitamin D to promote differentiation and apoptosis has been demonstrated in vitro and in preclinical studies in myelodysplastic syndromes (MDS) and acute myeloid leukemia (AML). Some degree of responses has been observed with vitamin D in these neoplasms although evidence is not strong enough to set recommendations in the clinical setting. Therefore, the use of vitamin $\mathrm{D}$ and analogs are on continuous investigation.

Calcitriol was discovered in 1981 to induce monocytic differentiation of the human promyelocytic leukemia cell line HL-60 [121]. Later, a similar effect was observed in other cell population lines such as THP-1 (monoblasts), HEL (bipotent erythroblasts-monoblasts), M1 (late myeloblasts) [122]. ATRA and calcitriol for the treatment of acute promyelocytic leukemia has proven to be an effective synergistic combination therapy for inducing differentiation and impairing cell growth. [123,124]. In addition, the analog KH1060 (modified 20-epi-1,25 dihydroxyvitamin $\mathrm{D}_{3}$ ) in combination with ATRA have been proven to be synergic and they induce differentiation, proliferation inhibition and induction of apoptosis.[125,126]. Other analogs have been tested in leukemic cells and showed to be more potent in vitro than calcitriol $[126,127]$. Also, the combination of paricalcitol and arsenic trioxide potently decreased growth and induced differentiation and apoptosis of AML cells. [128].

Low serum levels of vitamin D have been reported in MDS [129] although the association with prognosis remains controversial. In a study reported by Pardanani, vitamin D levels did not correlate with prognosis in a series of 409 patients diagnosed with differ- 
ent myeloid neoplasms and MDS [130]. By contrast, levels of vitamin D were an independent predictor of survival in a retrospective study of 58 patients with MDS or secondary oligoblastic AML treated with to 5-azacytidine (AZA) with an estimated probability of 2year overall survival of $40 \%$ for high vitamin D levels group versus $14 \%$ for low levels ( $p$ $<0.05)$. The AZA and 25-hydroxyvitamin $\mathrm{D}_{3}$ combination were also tested in-vitro showing a synergistic effect [131]. Similarly, a worse relapse-free survival was observed in AML patients with low vitamin D levels [132].

Regarding clinical studies on myelodysplastic syndromes, Koeffler [133] reported a minor response in 8 out of 18 patients treated with calcitriol at doses $>2 \mu \mathrm{g} /$ day but hypercalcemia was also observed in 8 patients. Mellibovsky [134] reported responses in 11 out of 19 patients treated with calcitriol $(0.25-0.75 \mu \mathrm{g} /$ day $)$ or calcifediol $266 \mu \mathrm{g}$ three times a week. No cases of hypercalcemia were registered. In this study, no correlation was observed between baseline levels of vitamin $\mathrm{D}$ metabolites and response.

Besides, two trials with paricalcitol at doses of $8 \mu \mathrm{g} /$ day [135] and doxercalciferol 12.5 $\mu \mathrm{g} /$ day [136] did not show a clinical benefit. By contrast, there is evidence of a potential effect on progression to AML. In this regard, Motomura et al. randomized a series of 30 patients to receive alfacalcidol versus supportive treatment [137]. Only one of the 15 patients who received alfacalcidol progressed to AML versus seven in the control group. Alfacalcidol also demonstrated an ORR of 30\% when combined with menatetrenone [138]. In addition, a study of 63 patients with myelodysplastic syndromes (MDS) and 15 with acute myelogenous leukemia (AML) were randomized to receive low-dose ara-C or low dose ara-C in combination with 13-cis-retinoic acid (13-CRA) and 1 alpha-hydroxyvitamin $\mathrm{D}_{3}$ showing that the addition of 13-CRA and 1 alpha-hydroxyvitamin $\mathrm{D}_{3}$ had no impact on survival or remission rates although a trend towards a lower rate of progression from MDS to AML was found ( $p=0.0527$ ) [139]. Also, erythroid responses as high as $60 \%$ have been reported in MDS with low risk International Prognostic Scoring System (IPSS) score treated with a combination of EPO, 13-CRA and calcitriol and with a median response duration of 16 months [140].

In 29 elderly patients with AML a combination of cytarabine $\left(20 \mathrm{mg} / \mathrm{m}^{2} /\right.$ day for 21 days), oral hydroxyurea (500 mg twice a day), and calcitriol (0.5 $\mathrm{mg}$ twice a day) followed by calcitriol maintenance was tested achieving $79 \%$ overall responses (34\% partial and $45 \%$ complete remission) with a duration of 9.8 months. Two cases of hypercalcemia were observed [141].

There are also data on the antitumoral effect of vitamin D in lymphoid neoplasms. A significant association between low serum vitamin D levels and survival in patients diagnosed with follicular lymphoma has been described [142]. Patients included in SWOG clinical trials, who were vitamin D deficient $(<20 \mathrm{ng} / \mathrm{mL} ; 15 \%$ of cohort), had an adjusted PFS and overall survival hazard ratios of 1.97 (95\% CI, 1.10 to 3.53) and 4.16 (95\% CI, 1.66 to 10.44), respectively (median follow-up of 5.4 years) [143].

Besides, a prospective study performed in 983 patients with non-Hodgkin lymphoma showed that vitamin D insufficiency $(<25 \mathrm{ng} / \mathrm{mL})$ in DLBCL was associated with inferior EFS (hazard ratio [HR], 1.41; 95\% CI, 0.98 to 2.04 ) and OS (HR, 1.99; 95\% CI, 1.27 to 3.13). T-cell lymphoma patients also had inferior EFS (HR, 1.94; 95\% CI, 1.04 to 3.61) and OS (HR, 2.38; 95\% CI, 1.04 to 5.41) [144].

A meta-analysis investigated the association between various measures of vitamin $\mathrm{D}$ status and the risk of developing non-Hodgkin lymphoma (NHL). Significant protective effects of overall sunlight/UVR exposure on NHL were observed, although risk estimates were inconsistent when dietary vitamin $\mathrm{D}$ intake and vitamin $\mathrm{D}$ levels were measured [145]. In mantle cell lymphoma, vitamin D deficiency was an independent prognosis factor for PFS [hazard ratio (HR) 3.713; 95\% confidence interval (CI) 1.822-7.565; P < 0.001], and OS (HR 8.305; 95\% CI 2.060-33.481; P =0.003), that was confirmed on multivariate analysis in which mantle cell international prognostic index was included [146]. Similarly, a decrease in PFS (HR 3.323, 95 \% CI 1.527-7.229, P = 0.002) and OS (HR 5.819, 95 \% CI 1.322-25.622, $\mathrm{P}=0.020$ ) have been observed in patients with Hodgkin lymphoma [147]. Another study that supports a poor prognosis among vitamin D deficient patients in 
Hodgkin lymphoma was carried out in 351 patients included in German Hodgkin Study Group clinical trials (HD7, HD8, and HD9). Interestingly, there is evidence of an improved outcome in patients with DLBCL with rituximab-based treatment who previously were deficient/insufficient for vitamin D and achieve normal levels after vitamin D3 supplementation [148]. A protective effect of vitamin D supplementation against the development of lymphoid malignancies has been reported in a randomized-controlled trial, which recruited 34763 women, aimed to evaluate the incidence skeletal fractures and cancer. Woman receiving vitamin D and calcium had HRs of 0.77 (95\% CI, 0.59-1.01) and 0.46 (95\% CI, 0.24-0.89), respectively, for cancer incidence and mortality. Despite some limitations, these results provide support for the design of vitamin D clinical trials [149]. Several clinical trials are ongoing to address the impact of vitamin $D$ replacement on the prognosis of lymphoid malignancies. (Table 1). A vitamin D replacement strategy in vitamin D insufficient patients with lymphoma or chronic lymphocytic leukemia has been successfully performed by Sfeir et al [150]. Target vitamin D level of $\geqslant 30 \mathrm{ng} / \mathrm{ml}$ were achieved in $97 \%$ of patients at the end of 12-week induction period. This strategy is being now evaluated in a clinical trial (NCT01787409) to analyze the impact on prognosis.

Regarding multiple myeloma, preclinical studies have shown activity of the vitamin D analogue EB1089 in cell line H929. This agent promotes apoptosis and induce cell cycle arrest by downregulation of cyclin-dependent kinases [151,152]. Although vitamin D deficiency is common in multiple myeloma, supplementation has not been found to improve the outcome of patients. Currently, the recommendations of vitamin D supplements are to improve bone and immune health in MGUS and MM patients [153].

\section{VITAMIN D AND ALLOGENEIC STEM CELL TRANSPLANTATION: EFFECT ON GRAFT-VERSUS-HOST DISEASE (GvHD)}

Patients undergoing allogenic hematopoietic stem cell transplantation (allo-HSCT) have a higher risk of VD deficiency than healthy population due to multiple factors, as previous studies have demonstrated [154]. The long-term hospitalizations decrease their sun exposure, and they are even counseled to minimize unprotected exposure to sunlight due to an increased risk of nonmelanoma skin cancer as well as potential activation of chronic GvHD [155]. Besides, Vitamin D absorption by the small intestine is often decreased due to gastrointestinal GvHD, infectious colitis or mucositis. Toxic treatments used in allo-HSCT also play a role in this deficiency: they can affect absorption too, reduce oral intake due to gastrointestinal toxicity and can interact with calcitriol throw CYP3A4 (e.g. calcineurin inhibitors, which, as VD, are substrates of this cytochrome). Finally, other possible complications, usually lead to renal or hepatic dysfunction, affecting vitamin D status as well $[85,155]$.

GvHD is one of the most frequent and severe complications after allo-HSCT; it is caused by the cytotoxic effect of the donor T lymphocytes to the recipient organs. Acute GvHD physiopathology involves T lymphocytes, natural killer cells and also the innate immune system [156]. In the case of chronic GvHD, a complex interaction between B and $\mathrm{T}$ lymphocytes leads to the production of auto-antibodies, cytokines and chemokines, which in turn induce the activation of the monocytic-macrophage system. Growth factors, such as TGFb, produced by wound-healing macrophages induces fibroblasts proliferation and the subsequent fibrosis of target organs.[157-159].

Considering the previously mentioned influence of vitamin $\mathrm{D}$ on regulation of the immune response and its potential effect on several hematologic malignancies, its role on allo-HSCT has been a great focus of interest. 
Patients undergoing hematopoietic stem cell transplant (HSCT) are at high risk for vitamin D deficiency before and after transplant $[160,161]$. The prevalence of vitamin D deficiency has been reported to be approximately of $30 \%$ in the general population and is significantly higher in this setting of HSCT (70\% before transplant and $90 \%$ after transplant $[161,162])$. Since vitamin D levels are not always monitored in HSCT patients and there is a high prevalence of vitamin D deficiency, Kenny et al. established a workflow for monitoring and treating vitamin D deficiency and to determine whether or not therapeutic vitamin D levels could be achieved posttransplant using a HSCT-specific vitamin D algorithm [155]. The initial replacement doses were serum vitamin D dependent and again a dose adjustment-based level was measured in several points. With the implementation of this algorithm, vitamin D deficiency decreased from $72.9 \%$ pretransplant to $26.4 \%$ posttransplant. Vitamin D supplementation in HSCT patients not always achieve optimal serum vitamin D levels [163]. Therefore, a more intensive vitamin D replacement than recommended for the general population may be required in HSCT patients [155].

Several studies have been reported describing a link between GvHD incidence and/or severity and vitamin D deficiency [164-168]. Some of them [165,167,168] specifically described an impact of vitamin D deficiency on chronic GvHD incidence. By contrast, others didn't find a significant correlation [161,169-177].

When we look at survival rates, it is also difficult to make a definitive statement. Beebe et al and Hansson et al $[167,170]$ described a worse overall survival and Perera et al [175] a higher mortality among patients with vitamin D deficiency, while Bhandari et al [174] found that vitamin D levels correlate with overall survival upon considering followup levels but not just vitamin D levels before HSCT.

In the largest study reported by Radujkovic et al [176] in 492 patients, a significant association between vitamin $\mathrm{D}$ deficiency and inferior overall survival was described (Hazard ratio 1.78; $\mathrm{P}=.007)$. This effect was due to a higher risk of relapse (HR 1.96, $\mathrm{P}=$ $.006)$ in myeloid diseases. This study did not find a relationship between vitamin $\mathrm{D}$ levels and incidence of acute or chronic GvHD.

In a meta-analysis, Ito et al [178] observed that lower vitamin D levels were associated with significantly poorer overall survival (HR: 1.50, 95\%CI 1.03-2.18) and a higher relapse rate (HR: 2.12, 95\%CI 1.41-3.19), while no significant impact on non-relapse mortality (NRM) was described (HR: 1.23, 95\%CI 0.72-2.10).

Another meta-analysis [179] concluded that vitamin D deficiency was not significantly associated with a higher risk of GvHD, although there was a trend for both acute [HR 1.06 (95\% CI 0.74-1.53, P > 0.05)] and chronic GvHD [HR 1.75 (95\% CI 0.72-4.26, P > 0.05)]. All these results are summarized on Table 2. With this background, Hong et al proposed that vitamin D levels should be monitored in all patients prior to allo-HSCT and every 3 months thereafter.

For monitoring purposes, as previously mentioned, the main circulating metabolite of vitamin $\mathrm{D}$ in serum is 25 -hydroxyvitamin $\mathrm{D}$ and is considered the most reliable marker [180]. However, Peter et al [177] set out the underestimated role of 1,25-dihydroxyvitamin$\mathrm{D}_{3}$ and its value to predict outcomes after of allo-HSCT. They measured 1,25-dihydroxyvitamin- $\mathrm{D}_{3}$ in 143 patients and compared their findings with 25-hydroxyvitamin D levels and found that only peritransplant 1,25-dihydroxyvitamin-D 3 deficiency was significantly associated with a higher 1-year-NRM. Afterwards, they studied 365 additional patients and again showed that patients with 1,25-dihydroxyvitamin- $\mathrm{D}_{3}$ levels below $139.5 \mathrm{pM}$ had a 3.3-fold increased risk of NRM (Cox-model unadjusted $\mathrm{P}<0.0005$, adjusted $\mathrm{P}=0.001)$.

Studies evaluating the efficacy of Vitamin D administration 
With these data in mind, several studies have evaluated the potential benefit of the administration of different subtypes or doses of vitamin D in the allo-HSCT setting (Table 3). Kenny et al [155] propose an ergocalciferol (or cholecalciferol) dose of up to $50000 \mathrm{IU}$ orally once weekly, and they got only $19.7 \%$ allogenic deficient patients after the transplant $(69.7 \%$ were deficient before it). They concluded that aggressive vitamin $\mathrm{D}$ repletion posttransplant decreases the incidence of VD deficiency.

Other studies included in Table 3 go further and relate the vitamin D supplementation with HSCT outcomes. One of them [181] analyzed the impact of VD administration on patients with active chronic GvHD, finding an improvement in severity and a remarkable reduction of relapses or progressions.

Bhandari et al. [182] designed a study in a pediatric population to evaluate whether a single, weight-based ultra-high dose of vitamin D -or Stoss dose- was more effective than standard supplementation to achieve pre-HSCT vitamin D sufficiency and reduce the incidence of HSCT-related complications that are associated with immune-mediated endothelial damage [182]. Stoss dose was given to 33 patients 14 days before conditioning and then a routine maintenance supplementation before day 100 in case of insufficiency. The outcome was compared to a historical cohort of 136 patients treated with standard supplementation. Low levels of vitamin D were present in $61 \%$ of patients and $97 \%$ of them maintain vitamin D sufficiency after the Stoss-dose compared to $67 \%(n=10 / 15)$ of patients in the historical control who were on standard supplementation at the time the total 25-OHD level was assessed $(\mathrm{P}=.013)$. There was a trend to lower combined incidence of HSCT-related complications in patients receiving Stoss-dosed vitamin D than the historical control $(25 \%[\mathrm{n}=7 / 28]$ versus $42 \%$ [ $\mathrm{n}=57 / 136], \mathrm{P}=.055)$. A randomized phase 4 trial have been performed to assess safety and efficacy of Stoss dose versus standard vitamin D replacement with awaiting results (NCT03176849). A summary of ongoing trials of vitamin D in HSCT setting is shown on table 4.

The Alovita trial was a prospective study which of 150 patients older than 18 years from 7 Spanish centers were included from May 2011 to February 2014 [183,184]. Three consecutive cohorts with 50 patients in each one were included: the control group (CG) did not receive cholecalciferol (vitamin $\mathrm{D}_{3}$ ), the second cohort or low-dose group (LdD) received 1,000 IU of vitamin $\mathrm{D}_{3}$ per day, and in the high-dose group (HdD), patients received 5,000 IU per day. Vitamin $\mathrm{D}_{3}$ was given orally from day -5 before transplant until day +100 after transplantation.

Regarding toxicity, no serious adverse events, specifically no case of hypercalcemia, were reported.

Vitamin $\mathrm{D}_{3}$ supplementation was proved to be effective in terms of reduction of chronic GvHD incidence. A decrease of both overall as well as moderate plus severe cGvHD incidence was observed in LdD at 1 year [37.5\% (95\% CI, 24.9-56.4) and 19.5\% (95\% CI, 10.4-36.7), respectively] and HdD [42.4\% (95\% CI, 29.3-61.4) and 27\% (95\% CI, 16.1-45.2), respectively] as compared with patients who did not receive vitamin D [67.5\% (95\% CI, 54.1-84.3) and 44.7\% (95\% CI, 31.2-64.2), respectively; $\mathrm{P}=0.019$ for overall and $\mathrm{P}$ $=0.026$ for moderate plus severe $\mathrm{cGvHD}$, respectively]. No significant differences were observed in terms of cumulative incidence of overall and grades 2-4 acute GvHD, cumulative incidence of relapse at 1 year. No either significant difference in DFS was observed nor OS with a median follow-up of 2 years.

This effect correlated with several biological parameters. The most significant differences between the 3 cohorts were a decrease on both the percentage and absolute number of circulating B cells on day 100 for LdD and HdD subgroups as compared with CG, a markedly modified ratio of naïve/memory/effector $\mathrm{T}$ cells, with a lower number of circulating naïve CD8+ among patients receiving vitamin D as compared with those who did not receive it and a significantly lower expression of CD40L as activation marker among patients receiving vitamin $\mathrm{D}$. These findings are concordant with an increase of immune 
tolerance development at the same time as survival and expansion of donor naïve $\mathrm{T}$ and B cells is impaired.

Next, we performed a retrospective study among patients previously included in the alovita trial to identify which factors might influence on the effect of vitamin D on cGvHD; particularly, we focused on the evaluation of the different VDR SNPs among patients and their respective donors who had genomic DNA stored before transplant [183]. Patients were gathered in two groups, vitamin D group, who received 1000 or 5000 UI daily $(n=71)$ and control group ( $\mathrm{n}=36)$. We investigated the SNPs FokI (rs2228570 T/C), BsmI (rs1544410 A/G), ApaI (rs7975232 C/A), and TaqI (rs731236 T/C) in 107 patients and 102 donors. We found that BsmI, ApaI, and TaqI alleles were in strong disequilibrium. In contrast, FokI did not demonstrate any association with BsmI, ApaI, or TaqI. Overall, there were no significant differences on the incidence of cGvHD depending on patients or donors SNPs. In contrast, VDR genotypes significantly influenced on the impact of vitamin D administration on $\mathrm{cGvHD}$ incidence. The administration of vit $\mathrm{D}$ significantly influenced on the risk of overall cGvHD among patients with FokI, CT [cGvHD incidence 22.5\% (95\% CI, 8.8-39) vs. $80 \%(95 \% \mathrm{CI}, 30.8-95)$ for patients receiving or not vit $\mathrm{D}$, respectively, $\mathrm{P}=0.0004$. The same genotype also influenced on the risk of moderate-severe cGvHD. We also evaluated the benefit obtained from the administration of vitamin D posttransplant depending on most frequent patients' BsmI/ApaI/TaqI haplotype. In this regard, patients carrying GGT/GGT genotype had the greatest benefit from receiving vitamin D in terms of cGvHD incidence although we could not confirm that data on multivariate analysis. In that analysis a significant interaction for the risk of overall cGvHD was observed between FokI genotype and vitamin D administration. Accordingly, the risk of cGvHD of patients treated with vitamin D was lower among patients carrying FokI CT genotype [adjusted hazard ratio (aHR) 0.143; 95\% CI, 0.045-0.452; Pinteraction < 0.001]. In addition, we performed analysis to evaluate the vitamin D supplementation impact on survival, relapse incidence and non-relapse mortality without finding any association.

Emphasizing the finding of a decreased risk of cGvHD among specific SNP (FokI) of the recipients, the effect of vitamin $\mathrm{D}$ in dendritic cells population might be the most relevant to justify the impact of vitamin D on cGvHD incidence. Some subtypes of dentritic cells from the host persist after engraftment and therefore, vitamin D binding VDR would inhibit their differentiation and maturation and would decrease alloreactive T-cell activation at the same time as it would upregulate tolerogenic properties selectively in myeloid dendritic cells.

In summary, the effect of vitamin D on hematopoietic cells, specially on the different cell subsets from the immune system, together with the previously mentioned data and the excellent toxicity profile support its use in the allo-HSCT setting in an attempt to decrease cGvHD. Additional studies are required to further explore its efficacy.

Author Contributions: ARG wrote the preclinical studies and the effect of vitamin D on the immune system; EC and GR described the studies on the efficacy of vitamin D in the treatment of hematologic malignancies; CMC and JAPS described the studies available analyzing the role of vitamin D in the allo-HSCT setting. All critically reviewed the manuscript

Funding: "This research received no external funding".

Acknowledgments: JAPS is funded by TerAv-RICORS, grant RD21/0017/0021. ARG is funded with a grant from the University of Seville with European Regional Development Fund (ERDF) program, grant US-1380874. The authors apologize to those colleagues whose work could not be cited due to the extension of the work.

Conflicts of Interest: JAPS has participated in educational sessions and/or research projects and/or advisory boards from AMGEN, JANSSEN, NOVARTIS, ALEXION, JAZZ, ABVVIE, BMS 
1. Feldman, D.; Pike, W.J.; Glorieux, F.H. Vitamin D. Vitam. D 2005, 1-2, doi:10.1016/B978-0-12-252687-9.X5000-1.

2. Sarafin, K.; Durazo-Arvizu, R.; Tian, L.; Phinney, K.W.; Tai, S.; Camara, J.E.; Merkel, J.; Green, E.; Sempos, C.T.; Brooks, S.P.J. Standardizing 25-hydroxyvitamin D values from the Canadian Health Measures Survey. Am. J. Clin. Nutr. 2015, 102, 1044-1050, doi:10.3945/AJCN.114.103689.

3. Schleicher, R.L.; Sternberg, M.R.; Looker, A.C.; Yetley, E.A.; Lacher, D.A.; Sempos, C.T.; Taylor, C.L.; DurazoArvizu, R.A.; Maw, K.L.; Chaudhary-Webb, M.; et al. National Estimates of Serum Total 25-Hydroxyvitamin D and Metabolite Concentrations Measured by Liquid Chromatography-Tandem Mass Spectrometry in the US Population during 2007-2010. J. Nutr. 2016, 146, 1051-1061, doi:10.3945/JN.115.227728.

4. Cashman, K.D. Vitamin D Deficiency: Defining, Prevalence, Causes, and Strategies of Addressing. Calcif. Tissue Int. 2020, 106, 14-29, doi:10.1007/S00223-019-00559-4/TABLES/1.

5. Cashman, K.D.; Dowling, K.G.; Škrabáková, Z.; Gonzalez-Gross, M.; Valtueña, J.; De Henauw, S.; Moreno, L.; Damsgaard, C.T.; Michaelsen, K.F.; Mølgaard, C.; et al. Vitamin D deficiency in Europe: pandemic? Am. J. Clin. Nutr. 2016, 103, 1033-1044, doi:10.3945/AJCN.115.120873.

6. Amrein, K.; Scherkl, M.; Hoffmann, M.; Neuwersch-Sommeregger, S.; Köstenberger, M.; Tmava Berisha, A.; Martucci, G.; Pilz, S.; Malle, O. Vitamin D deficiency 2.0: an update on the current status worldwide. Eur. J. Clin. Nutr. 20207411 2020, 74, 1498-1513, doi:10.1038/s41430-020-0558-y.

7. Dusso, A.S.; Brown, A.J.; Slatopolsky, E. Vitamin D. Am. J. Physiol. - Ren. Physiol. 2005, 289, 8-28, doi:10.1152/AJPRENAL.00336.2004/ASSET/IMAGES/LARGE/ZH20070519960008.JPEG.

8. Mellanby Discussion on the Importance of Accessory Food Factors (Vitamines) in the Feeding of Infants. Proc. R. Soc. Med. 1920, 13, 95-98, doi:10.1177/003591572001301927.

9. Lawson, D.E.M.; Fraser, D.R.; Kodicek, E.; Morris, H.R.; Williams, D.H. Identification of 1,25dihydroxycholecalciferol, a new kidney hormone controlling calcium metabolism. Nature 1971, 230, 228-230, doi:10.1038/230228A0.

10. Holick, M.F.; Schnoes, H.K.; DeLuca, H.F.; Suda, T.; Cousins, R.J. Isolation and Identification of 1,25Dihydroxycholecalciferol. a Metabolite of Vitamin D Active in Intestine. Biochemistry 1971, 10, 2799-2804, doi:10.1021/BI00790A023.

11. Norman, A.W.; Myrtle, J.F.; Midgett, R.J.; Nowicki, H.G.; Williams, V.; Popják, G. 1,25-Dihydroxy cholecalciferol: Identification of the proposed active form of vitamin D3 in the intestine. Science (80-. ). 1971, 173, 51-54, doi:10.1126/SCIENCE.173.3991.51.

12. Fu, G.K.; Lin, D.; Zhang, M.Y.H.; Bikle, D.D.; Shackleton, C.H.L.; Miller, W.L.; Portale, A.A. Cloning of human 25-hydroxyvitamin D-1 alpha-hydroxylase and mutations causing vitamin D-dependent rickets type 1 . Mol. Endocrinol. 1997, 11, 1961-1970, doi:10.1210/MEND.11.13.0035.

13. Monkawa, T.; Yoshida, T.; Wakino, S.; Shinki, T.; Anazawa, H.; DeLuca, H.F.; Suda, T.; Hayashi, M.; Saruta, T. Molecular cloning of cDNA and genomic DNA for human 25-hydroxyvitamin D3 1 alpha-hydroxylase. Biochem. 
Biophys. Res. Commun. 1997, 239, 527-533, doi:10.1006/BBRC.1997.7508.

14. Jones, G.; Prosser, D.E.; Kaufmann, M. 25-Hydroxyvitamin D-24-hydroxylase (CYP24A1): Its important role in the degradation of vitamin D. Arch. Biochem. Biophys. 2012, 523, 9-18, doi:10.1016/J.ABB.2011.11.003.

15. Haussler, M.R.; Whitfield, G.K.; Kaneko, I.; Haussler, C.A.; Hsieh, D.; Hsieh, J.-C.; Jurutka, P.W. Molecular mechanisms of vitamin D action. Calcif. Tissue Int. 2013, 92, 77-98, doi:10.1007/s00223-012-9619-0.

16. Brown, A.J.; Dusso, A.; Slatopolsky, E. Vitamin D. Am. J. Physiol. - Ren. Physiol. 1999, 277, 157-175, doi:10.1152/AJPRENAL.1999.277.2.F157/ASSET/IMAGES/LARGE/AFLU20813005DX.JPEG.

17. Cheskis, B.; Freedman, L.P. Ligand modulates the conversion of DNA-bound vitamin D3 receptor (VDR) homodimers into VDR-retinoid X receptor heterodimers. Mol. Cell. Biol. 1994, 14, 3329-3338, doi:10.1128/MCB.14.5.3329-3338.1994.

18. Umesono, K.; Murakami, K.K.; Thompson, C.C.; Evans, R.M. Direct repeats as selective response elements for the thyroid hormone, retinoic acid, and vitamin D3 receptors. Cell 1991, 65, 1255-1266, doi:10.1016/00928674(91)90020-Y.

19. Bikle, D.D. Ligand-Independent Actions of the Vitamin D Receptor: More Questions Than Answers. JBMR plus 2021, 5, doi:10.1002/JBM4.10578.

20. Skorija, K.; Cox, M.; Sisk, J.M.; Dowd, D.R.; MacDonald, P.N.; Thompson, C.C.; Demay, M.B. LigandIndependent Actions of the Vitamin D Receptor Maintain Hair Follicle Homeostasis. Mol. Endocrinol. 2005, 19, 855-862, doi:10.1210/ME.2004-0415.

21. Ellison, T.I.; Smith, M.K.; Gilliam, A.C.; MacDonald, P.N. Inactivation of the Vitamin D Receptor Enhances Susceptibility of Murine Skin to UV-Induced Tumorigenesis. J. Invest. Dermatol. 2008, 128, 2508-2517, doi:10.1038/JID.2008.131.

22. Harris, S.S.; Eccleshall, T.R.; Gross, C.; Dawson-Hughes, B.; Feldman, D. The vitamin D receptor start codon polymorphism (FokI) and bone mineral density in premenopausal American black and white women. J. Bone Miner. Res. 1997, 12, 1043-1048, doi:10.1359/JBMR.1997.12.7.1043.

23. Faraco, J.H.; Morrison, N.A.; Baker, A.; Shine, J.; Frossard, P.M. ApaI dimorphism at the human vitamin D receptor gene locus. Nucleic Acids Res. 1989, 17, 2150, doi:10.1093/NAR/17.5.2150.

24. Morrison, N.A.; Yeoman, R.; Kelly, P.J.; Eisman, J.A. Contribution of trans-acting factor alleles to normal physiological variability: vitamin D receptor gene polymorphism and circulating osteocalcin. Proc. Natl. Acad. Sci. 1992, 89, 6665-6669, doi:10.1073/PNAS.89.15.6665.

25. Morrison, N.A.; Qi, J.C.; Tokita, A.; Kelly, P.J.; Crofts, L.; Nguyen, T. V.; Sambrook, P.N.; Eisman, J.A. Prediction of bone density from vitamin D receptor alleles. Nat. 19943676460 1994, 367, 284-287, doi:10.1038/367284a0.

26. Uitterlinden, A.G.; Fang, Y.; van Meurs, J.B.J.; Pols, H.A.P.; van Leeuwen, J.P.T.M. Genetics and biology of vitamin D receptor polymorphisms. Gene 2004, 338, 143-156, doi:10.1016/j.gene.2004.05.014. 
27. Uitterlinden, A.G.; Pols, H.A.P.; Burger, H.; Huang, Q.; Van Daele, P.L.A.; Van Duijn, C.M.; Hofman, A.; Birkenhäger, J.C.; Van Leeuwen, J.P.T.M. A large-scale population-based study of the association of vitamin D receptor gene polymorphisms with bone mineral density. J. Bone Miner. Res. 1996, 11, 1241-1248, doi:10.1002/JBMR.5650110908.

28. van Etten, E.; Verlinden, L.; Giulietti, A.; Ramos-Lopez, E.; Branisteanu, D.D.; Ferreira, G.B.; Overbergh, L.; Verstuyf, A.; Bouillon, R.; Roep, B.O.; et al. The vitamin D receptor gene FokI polymorphism: Functional impact on the immune system. Eur. J. Immunol. 2007, 37, 395-405, doi:10.1002/EJI.200636043.

29. Bikle, D. Nonclassic actions of vitamin D. J. Clin. Endocrinol. Metab. 2009, 94, 26-34.

30. Provvedini, D.M.; Tsoukas, C.D.; Deftos, L.J.; Manolagas, S.C. 1,25-Dihydroxyvitamin D3 Receptors in Human Leukocytes. Science (80-. ). 1983, 221, 1181-1183, doi:10.1126/SCIENCE.6310748.

31. Chen, W.C.; Vayuvegula, B.; Gupta, S. 1,25-Dihydroxyvitamin D3-mediated inhibition of human B cell differentiation. Clin. Exp. Immunol. 1987, 69, 639-46.

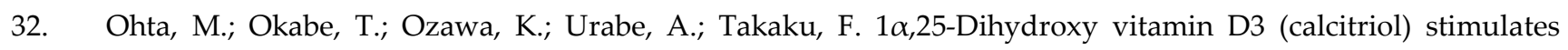
proliferation of human circulating monocytes in vitro. FEBS Lett. 1985, 185, 9-13, doi:10.1016/00145793(85)80730-4.

33. Hodler, B.; EvẾquoz, V.; Trechsel, U.; Fleisch, H.; Stadler, B. Influence of Vitamin D3 Metabolites on the Production of Interleukins 1, 2 and 3. Immunobiology 1985, 170, 256-269, doi:10.1016/S0171-2985(85)80075-9.

34. Lemire, J.M.; Adams, J.S.; Kermani-Arab, V.; Bakke, A.C.; Sakai, R.; Jordan, S.C. 1,25-Dihydroxyvitamin D3 suppresses human T helper/inducer lymphocyte activity in vitro. J. Immunol. 1985, 134, 3032-5.

35. Lemire, J.M.; Adams, J.S.; Sakai, R.; Jordan, S.C. 1 alpha,25-dihydroxyvitamin D3 suppresses proliferation and immunoglobulin production by normal human peripheral blood mononuclear cells. J. Clin. Invest. 1984, 74, 657661, doi:10.1172/JCI111465.

36. Abe, E.; Miyaura, C.; Sakagami, H.; Takeda, M.; Konno, K.; Yamazaki, T.; Yoshiki, S.; Suda, T. Differentiation of mouse myeloid leukemia cells induced by 1 alpha,25-dihydroxyvitamin D3. Proc. Natl. Acad. Sci. 1981, 78, 49904994, doi:10.1073/PNAS.78.8.4990.

37. Davies, P.D. 0. A possible link between vitamin d deficiency and impaired host defence to mycobacterium tuberculosis. Tubercle 1985, 66, 301-306, doi:10.1016/0041-3879(85)90068-6.

38. Green, M. Cod liver oil and tuberculosis. BMJ 2011, 343, doi:10.1136/BMJ.D7505.

39. Rolf, L.; Muris, A.H.; Hupperts, R.; Damoiseaux, J. Vitamin D effects on B cell function in autoimmunity. Ann. N. Y. Acad. Sci. 2014, 1317, 84-91, doi:10.1111/NYAS.12440.

40. Veldman, C.M.; Cantorna, M.T.; DeLuca, H.F. Expression of 1,25-dihydroxyvitamin D(3) receptor in the immune system. Arch. Biochem. Biophys. 2000, 374, 334-8, doi:10.1006/abbi.1999.1605.

41. Edfeldt, K.; Liu, P.T.; Chun, R.; Fabri, M.; Schenk, M.; Wheelwright, M.; Keegan, C.; Krutzik, S.R.; Adams, J.S.; 
Hewison, M.; et al. T-cell cytokines differentially control human monocyte antimicrobial responses by regulating vitamin D metabolism. Proc. Natl. Acad. Sci. 2010, 107, 22593-22598, doi:10.1073/PNAS.1011624108.

42. Baeke, F.; Korf, H.; Overbergh, L.; van Etten, E.; Verstuyf, A.; Gysemans, C.; Mathieu, C. Human T lymphocytes are direct targets of 1,25-dihydroxyvitamin D3 in the immune system. J. Steroid Biochem. Mol. Biol. 2010, 121, 221227, doi:10.1016/J.JSBMB.2010.03.037.

43. Baeke, F.; Takiishi, T.; Korf, H.; Gysemans, C.; Mathieu, C. Vitamin D: modulator of the immune system. Curr. Opin. Pharmacol. 2010, 10, 482-496, doi:10.1016/J.COPH.2010.04.001.

44. Hewison, M. An update on vitamin D and human immunity. Clin. Endocrinol. (Oxf). 2012, 76, 315-325, doi:10.1111/j.1365-2265.2011.04261.x.

45. Liu, P.T.; Stenger, S.; Li, H.; Wenzel, L.; Tan, B.H.; Krutzik, S.R.; Ochoa, M.T.; Schauber, J.; Wu, K.; Meinken, C.; et al. Toll-like receptor triggering of a vitamin D-mediated human antimicrobial response. Science (80-. ). 2006, 311, 1770-1773.

46. Gombart, A.F.; Borregaard, N.; Koeffler, H.P. Human cathelicidin antimicrobial peptide (CAMP) gene is a direct target of the vitamin D receptor and is strongly up-regulated in myeloid cells by 1,25-dihydroxyvitamin D3. FASEB J. 2005, 19, 1067-1077, doi:10.1096/FJ.04-3284COM.

47. Wang, T.-T.; Nestel, F.P.; Bourdeau, V.; Nagai, Y.; Wang, Q.; Liao, J.; Tavera-Mendoza, L.; Lin, R.; Hanrahan, J.W.; Mader, S.; et al. Cutting Edge: 1,25-Dihydroxyvitamin D3 Is a Direct Inducer of Antimicrobial Peptide Gene Expression. J. Immunol. 2004, 173, 2909-2912, doi:10.4049/JIMMUNOL.173.5.2909.

48. Zhang, Y.; Leung, D.Y.M.; Richers, B.N.; Liu, Y.; Remigio, L.K.; Riches, D.W.; Goleva, E. Vitamin D Inhibits Monocyte/Macrophage Proinflammatory Cytokine Production by Targeting MAPK Phosphatase-1. J. Immunol. 2012, 188, 2127-2135, doi:10.4049/jimmunol.1102412.

49. Fabri, M.; Stenger, S.; Shin, D.M.; Yuk, J.M.; Liu, P.T.; Realegeno, S.; Lee, H.M.; Krutzik, S.R.; Schenk, M.; Sieling, P.A.; et al. Vitamin D is required for IFN- $\gamma$-mediated antimicrobial activity of human macrophages. Sci. Transl. Med. 2011, 3, doi:10.1126/SCITRANSLMED.3003045/SUPPL_FILE/3-104RA102_SM.PDF.

50. Gauzzi, M.C.; Purificato, C.; Donato, K.; Jin, Y.; Wang, L.; Daniel, K.C.; Maghazachi, A.A.; Belardelli, F.; Adorini, L.; Gessani, S. Suppressive Effect of $1 \alpha, 25$-Dihydroxyvitamin D 3 on Type I IFN-Mediated Monocyte Differentiation into Dendritic Cells: Impairment of Functional Activities and Chemotaxis . J. Immunol. 2005, 174, 270-276, doi:10.4049/jimmunol.174.1.270.

51. Small, A.G.; Harvey, S.; Kaur, J.; Putty, T.; Quach, A.; Munawara, U.; Perveen, K.; McPhee, A.; Hii, C.S.; Ferrante, A. Vitamin D upregulates the macrophage complement receptor immunoglobulin in innate immunity to microbial pathogens. 2021, 4, doi:10.1038/s42003-021-01943-3.

52. Merad, M.; Sathe, P.; Helft, J.; Miller, J.; Mortha, A. The Dendritic Cell Lineage: Ontogeny and Function of Dendritic Cells and Their Subsets in the Steady State and the Inflamed Setting. http://dx.doi.org/10.1146/annurevimmunol-020711-074950 2013, 31, 563-604, doi:10.1146/ANNUREV-IMMUNOL-020711-074950. 
53. Bscheider, M.; Butcher, E.C. Vitamin D immunoregulation through dendritic cells. Immunology 2016, 148, 227236, doi:10.1111/IMM.12610.

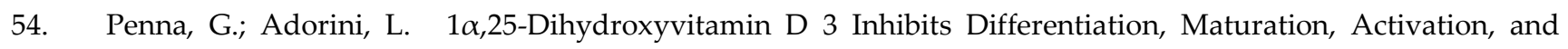
Survival of Dendritic Cells Leading to Impaired Alloreactive T Cell Activation . J. Immunol. 2000, 164, 2405-2411, doi:10.4049/JIMMUNOL.164.5.2405.

55. Griffin, M.D.; Lutz, W.; Phan, V.A.; Bachman, L.A.; McKean, D.J.; Kumar, R. Dendritic cell modulation by $1 \alpha, 25$ dihydroxyvitamin D3 and its analogs: A vitamin D receptor-dependent pathway that promotes a persistent state of immaturity in vitro and in vivo. Proc. Natl. Acad. Sci. 2001, 98, 6800-6805, doi:10.1073/PNAS.121172198.

56. Ferreira, G.B.; Vanherwegen, A.S.; Eelen, G.; Gutiérrez, A.C.F.; VanLommel, L.; Marchal, K.; Verlinden, L.; Verstuyf, A.; Nogueira, T.; Georgiadou, M.; et al. Vitamin D3 Induces Tolerance in Human Dendritic Cells by Activation of Intracellular Metabolic Pathways. Cell Rep. 2015, 10, 711-725, doi:10.1016/J.CELREP.2015.01.013.

57. Enioutina, E.Y.; Bareyan, D.; Daynes, R.A. Vitamin D3-mediated alterations to myeloid dendritic cell trafficking in vivo expand the scope of their antigen presenting properties. Vaccine 2007, 25, 1236-1249, doi:10.1016/J.VACCINE.2006.10.008.

58. Sigmundsdottir, H.; Pan, J.; Debes, G.F.; Alt, C.; Habtezion, A.; Soler, D.; Butcher, E.C. DCs metabolize sunlightinduced vitamin D3 to "program" T cell attraction to the epidermal chemokine CCL27. 2007, 8, $285-293$.

59. Takahashi, K.; Nakayama, Y.; Horiuchi, H.; Ohta, T.; Komoriya, K.; Ohmori, H.; Kamimura, T. Human neutrophils express messenger RNA of vitamin D receptor and respond to 1alpha,25-dihydroxyvitamin D3. Immunopharmacol. Immunotoxicol. 2002, 24, 335-47, doi:10.1081/iph-120014721.

60. Boeltz, S.; Amini, P.; Anders, H.J.; Andrade, F.; Bilyy, R.; Chatfield, S.; Cichon, I.; Clancy, D.M.; Desai, J.; Dumych, T.; et al. To NET or not to NET:current opinions and state of the science regarding the formation of neutrophil extracellular traps. Cell Death Differ. 2019, 26, 395-408.

61. Papayannopoulos, V. Neutrophil extracellular traps in immunity and disease. Nat. Rev. Immunol. 2018, 18, 134147, doi:10.1038/nri.2017.105.

62. Agraz-Cibrian, J.M.; Giraldo, D.M.; Urcuqui-Inchima, S. 1,25-Dihydroxyvitamin D3 induces formation of neutrophil extracellular trap-like structures and modulates the transcription of genes whose products are neutrophil extracellular trap-associated proteins: A pilot study. Steroids 2019, 141, 14-22, doi:10.1016/j.steroids.2018.11.001.

63. Weeres, M.A.; Robien, K.; Ahn, Y.-O.; Neulen, M.-L.; Bergerson, R.; Miller, J.S.; Verneris, M.R. The Effects of 1,25Dihydroxyvitamin D3 on In Vitro Human NK Cell Development from Hematopoietic Stem Cells. J. Immunol. 2014, 193, 3456-3462, doi:10.4049/JIMMUNOL.1400698.

64. Joseph, R.W.; Bayraktar, U.D.; Kim, T.K.; John, S.L.S.; Popat, U.; Khalili, J.; Molldrem, J.J.; Wieder, E.D.; Komanduri, K. V. Vitamin D receptor upregulation in alloreactive human T cells. Hum. Immunol. 2012, 73, 693698, doi:10.1016/J.HUMIMM.2012.04.019. 
65. Hayes, C.E.; Hubler, S.L.; Moore, J.R.; Barta, L.E.; Praska, C.E.; Nashold, F.E. Vitamin D actions on CD4+ T cells in autoimmune disease. Front. Immunol. 2015, 6, 100.

66. O’Kelly, J.; Hisatake, J.; Hisatake, Y.; Bishop, J.; Norman, A.; Koeffler, H.P.; O’Kelly, J.; Hisatake, J.; Hisatake, Y.; Bishop, J.; et al. Normal myelopoiesis but abnormal $\mathrm{T}$ lymphocyte responses in vitamin $\mathrm{D}$ receptor knockout mice. J. Clin. Invest. 2002, 109, 1091-1099, doi:10.1172/JCI12392.

67. Yu, S.; Bruce, D.; Froicu, M.; Weaver, V.; Cantorna, M.T. Failure of T cell homing, reduced CD4/CD8 $\alpha \alpha$ intraepithelial lymphocytes, and inflammation in the gut of vitamin D receptor KO mice. 2008, 105, 20834-20839, doi:10.1073/PNAS.0808700106.

68. Lemire, J.M.; Archer, D.C.; Beck, L.; Spiegelberg, H.L. Immunosuppressive actions of 1,25-dihydroxyvitamin D3: Preferential inhibition of Th1 functions. J. Nutr. 1995, 125, doi:10.1093/JN/125.SUPPL_6.1704S.

69. Von Essen, M.R.; Kongsbak, M.; Schjerling, P.; Olgaard, K.; Ødum, N.; Geisler, C. Vitamin D controls T cell antigen receptor signaling and activation of human T cells. Nat. Immunol. 2010, 11, 344-349.

70. Chambers, E.S.; Hawrylowicz, C.M. The impact of vitamin D on regulatory T cells. Curr. Allergy Asthma Rep. 2011, 11, 29-36, doi:10.1007/s11882-010-0161-8.

71. Unger, W.W.J.J.; Laban, S.; Kleijwegt, F.S.; Van Der Slik, A.R.; Roep, B.O. Induction of Treg by monocyte-derived DC modulated by vitamin D3 or dexamethasone: Differential role for PD-L1. Eur. J. Immunol. 2009, 39, 3147-3159, doi:10.1002/eji.200839103.

72. Gregori, S.; Casorati, M.; Amuchastegui, S.; Smiroldo, S.; Davalli, A.M.; Adorini, L. Regulatory T Cells Induced by 1 $\alpha, 25$-Dihydroxyvitamin D 3 and Mycophenolate Mofetil Treatment Mediate Transplantation Tolerance. J. Immunol. 2001, 167, 1945-1953, doi:10.4049/jimmunol.167.4.1945.

73. Urry, Z.; Chambers, E.S.; Xystrakis, E.; Dimeloe, S.; Richards, D.F.; Gabryšová, L.; Christensen, J.; Gupta, A.; Saglani, S.; Bush, A.; et al. The role of 1 $\alpha, 25$-dihydroxyvitamin D3 and cytokines in the promotion of distinct Foxp3+and IL-10+ CD4+ T cells. Eur. J. Immunol. 2012, 42, 2697-2708, doi:10.1002/EJI.201242370.

74. Zhou, Q.; Qin, S.; Zhang, J.; Zhon, L.; Pen, Z.; Xing, T. 1,25(OH)2D3 induces regulatory T cell differentiation by influencing the VDR/PLC- $\gamma 1 /$ TGF- $\beta 1 /$ pathway. Mol. Immunol. 2017, 91, 156-164, doi:10.1016/j.molimm.2017.09.006.

75. Chen, S.S.S.; Sims, G.P.; Chen, X.X.; Gu, Y.Y.; Chen, S.S.S.; Lipsky, P.E. Modulatory effects of 1,25dihydroxyvitamin D3 on human B cell differentiation. J. Immunol. 2007, 179, 1634-1647, doi:10.4049/jimmunol.179.3.1634.

76. Provvedini, D.M.; Tsoukas, C.D.; Deftos, L.J.; Manolagas, S.C. 1 alpha,25-Dihydroxyvitamin D3-binding macromolecules in human B lymphocytes: effects on immunoglobulin production. J. Immunol. 1986, 136, 273440 .

77. Iho, S.; Takahashi, T.; Kura, F.; Sugiyama, H.; Hoshino, T. The effect of 1,25-dihydroxyvitamin D3 on in vitro immunoglobulin production in human B cells. J. Immunol. 1986, 136, 4427-31. 
78. Hartmann, B.; Heine, G.; Babina, M.; Steinmeyer, A.; Zügel, U.; Radbruch, A.; Worm, M. Targeting the vitamin D receptor inhibits the B cell-dependent allergic immune response. Allergy Eur. J. Allergy Clin. Immunol. 2011, 66, 540-548, doi:10.1111/J.1398-9995.2010.02513.X.

79. Heine, G.; Niesner, U.; Chang, H.D.; Steinmeyer, A.; Zügel, U.; Zuberbier, T.; Radbruch, A.; Worm, M. 1,25dihydroxyvitamin D3 promotes IL-10 production in human B cells. Eur. J. Immunol. 2008, 38, 2210-2218, doi:10.1002/EJI.200838216.

80. Matsumoto, M.; Baba, A.; Yokota, T.; Nishikawa, H.; Ohkawa, Y.; Kayama, H.; Kallies, A.; Nutt, S.L.; Sakaguchi, S.; Takeda, K.; et al. Interleukin-10-producing plasmablasts exert regulatory function in autoimmune inflammation. Immunity 2014, 41, 1040-1051, doi:10.1016/J.IMMUNI.2014.10.016/ATTACHMENT/35D570476E4D-4CE8-8FDC-1B8B33BA1339/MMC1.PDF.

81. Rolf, L.; Muris, A.H.; Hupperts, R.; Damoiseaux, J. Illuminating vitamin D effects on B cells - the multiple sclerosis perspective. Immunology 2016, 147, 275-284, doi:10.1111/IMM.12572.

82. Ao, T.; Kikuta, J.; Ishii, M. The Effects of Vitamin D on Immune System and Inflammatory Diseases. Biomolecules 2021, 11, 1624, doi:10.3390/biom11111624.

83. Ghelani, D.; Alesi, S.; Mousa, A. Vitamin D and COVID-19: An Overview of Recent Evidence. Int. J. Mol. Sci. 2021, Vol. 22, Page 10559 2021, 22, 10559, doi:10.3390/IJMS221910559.

84. Soto, J.R.; Anthias, C.; Madrigal, A.; Snowden, J.A. Insights Into the Role of Vitamin D as a Biomarker in Stem Cell Transplantation. Front. Immunol. 2020, 11, doi:10.3389/FIMMU.2020.00966.

85. Hong, S.; Ferraro, C.S.; Hamilton, B.K.; Majhail, N.S. To D or not to D: vitamin D in hematopoietic cell transplantation. Bone Marrow Transplant. 2020, 55, 2060-2070, doi:10.1038/s41409-020-0904-7.

86. Medrano, M.; Carrillo-Cruz, E.; Montero, I.; Perez-Simon, J.A. Vitamin D: Effect on Haematopoiesis and Immune System and Clinical Applications. Int. J. Mol. Sci. 2018, 19, 2663, doi:10.3390/ijms19092663.

87. Jeon, S.M.; Shin, E.A. Exploring vitamin D metabolism and function in cancer. Exp. Mol. Med. 2018 504 2018, 50, 1-14, doi:10.1038/s12276-018-0038-9.

88. Adorini, L.; Penna, G.; Giarratana, N.; Uskokovic, M. Tolerogenic dendritic cells induced by vitamin D receptor ligands enhance regulatory $\mathrm{T}$ cells inhibiting allograft rejection and autoimmune diseases. In Proceedings of the Journal of Cellular Biochemistry; 2003; Vol. 88, pp. 227-233.

89. Xi, Y.; Ma, Y.; Xie, B.; Di, A.; Xu, S.; Luo, X.; Wang, C.; Dai, H.; Yan, G.; Qi, Z. Vitamin D3 combined with antibody agents suppresses alloreactive memory T-cell responses to induce heart allograft long-term survival. Transpl. Immunol. 2021, 66, 101374, doi:10.1016/j.trim.2021.101374.

90. Infante, M.; Ricordi, C.; Padilla, N.; Alvarez, A.; Linetsky, E.; Lanzoni, G.; Mattina, A.; Bertuzzi, F.; Fabbri, A.; Baidal, D.; et al. The Role of Vitamin D and Omega-3 PUFAs in Islet Transplantation. Nutr. 2019, Vol. 11, Page 2937 2019, 11, 2937, doi:10.3390/NU11122937. 


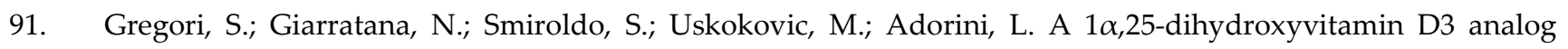
enhances regulatory T-cells and arrests autoimmune diabetes in NOD mice. Diabetes 2002, 51, 1367-1374, doi:10.2337/DIABETES.51.5.1367.

92. Giarratana, N.; Penna, G.; Amuchastegui, S.; Mariani, R.; Daniel, K.C.; Adorini, L. A Vitamin D Analog DownRegulates Proinflammatory Chemokine Production by Pancreatic Islets Inhibiting T Cell Recruitment and Type 1 Diabetes Development. J. Immunol. 2004, 173, 2280-2287, doi:10.4049/JIMMUNOL.173.4.2280.

93. Gysemans, C.; Van Etten, E.; Overbergh, L.; Giulietti, A.; Eelen, G.; Waer, M.; Verstuyf, A.; Bouillon, R.; Mathieu, C. Unaltered Diabetes Presentation in NOD Mice Lacking the Vitamin D Receptor. Diabetes 2008, 57, 269-275, doi:10.2337/DB07-1095.

94. Spach, K.M.; Nashold, F.E.; Dittel, B.N.; Hayes, C.E. IL-10 Signaling Is Essential for 1,25-Dihydroxyvitamin D 3 -Mediated Inhibition of Experimental Autoimmune Encephalomyelitis . J. Immunol. 2006, 177, 6030-6037, doi:10.4049/JIMMUNOL.177.9.6030.

95. Pedersen, L.B.; Nashold, F.E.; Spach, K.M.; Hayes, C.E. 1,25-Dihydroxyvitamin D3 reverses experimental autoimmune encephalomyelitis by inhibiting chemokine synthesis and monocyte trafficking. J. Neurosci. Res. 2007, 85, 2480-2490, doi:10.1002/JNR.21382.

96. Nashold, F.E.; Hoag, K.A.; Goverman, J.; Hayes, C.E. Rag-1-dependent cells are necessary for 1,25dihydroxyvitamin D3 prevention of experimental autoimmune encephalomyelitis. J. Neuroimmunol. 2001, 119, 16-29, doi:10.1016/S0165-5728(01)00360-5.

97. Meehan, T.F.; DeLuca, H.F. CD8+ T cells are not necessary for $1 \alpha, 25$-dihydroxy-vitamin D3 to suppress experimental autoimmune encephalomyelitis in mice. Proc. Natl. Acad. Sci. U. S. A. 2002, 99, 5557-5560, doi:10.1073/PNAS.082100699.

98. Mayne, C.G.; Spanier, J.A.; Relland, L.M.; Williams, C.B.; Hayes, C.E. 1,25-Dihydroxyvitamin D3 acts directly on the $\mathrm{T}$ lymphocyte vitamin $\mathrm{D}$ receptor to inhibit experimental autoimmune encephalomyelitis. Eur. J. Immunol. 2011, 41, 822-832, doi:10.1002/EJI.201040632.

99. Lemire, J.M.; Ince, A.; Takashima, M. 1,25-Dihydroxyvitamin D3 Attenuates of Expression of Experimental Murine Lupus of MRL/1 Mice. https://doi.org/10.3109/08916939209150321 2009, 12, 143-148, doi:10.3109/08916939209150321.

100. Reeves, W.H.; Lee, P.Y.; Weinstein, J.S.; Satoh, M.; Lu, L. Induction of autoimmunity by pristane and other naturally occurring hydrocarbons. Trends Immunol. 2009, 30, 455-464, doi:10.1016/J.IT.2009.06.003.

101. Correa Freitas, E.; Evelyn Karnopp, T.; de Souza Silva, J.M.; Cavalheiro do Espírito Santo, R.; da Rosa, T.H.; de Oliveira, M.S.; da Costa Gonçalves, F.; de Oliveira, F.H.; Guilherme Schaefer, P.; André Monticielo, O. Vitamin D supplementation ameliorates arthritis but does not alleviates renal injury in pristane-induced lupus model. https://doi.org/10.1080/08916934.2019.1613383 2019, 52, 69-77, doi:10.1080/08916934.2019.1613383.

102. Zhu, Y.; Mahon, B.D.; Froicu, M.; Cantorna, M.T. Calcium and 1alpha,25-dihydroxyvitamin D3 target the TNFalpha pathway to suppress experimental inflammatory bowel disease. Eur J Immunol 2005, 35, 217-224, 
doi:10.1002/eji.200425491.

103. Froicu, M.; Cantorna, M.T. Vitamin D and the vitamin D receptor are critical for control of the innate immune response to colonic injury. BMC Immunol. 2007, 8, 1-11, doi:10.1186/1471-2172-8-5/FIGURES/7.

104. Lagishetty, V.; Misharin, A. V.; Liu, N.Q.; Lisse, T.S.; Chun, R.F.; Ouyang, Y.; McLachlan, S.M.; Adams, J.S.; Hewison, M. Vitamin D Deficiency in Mice Impairs Colonic Antibacterial Activity and Predisposes to Colitis. Endocrinology 2010, 151, 2423-2432, doi:10.1210/EN.2010-0089.

105. Pakkala, I.; Taskinen, E.; Pakkala, S.; Räisänen-Sokolowski, A. MC1288, a vitamin D analog, prevents acute graftversus-host disease in rat bone marrow transplantation. Bone Marrow Transplant. 2001, 27, 863-867, doi:10.1038/sj.bmt.1702873.

106. Taylor, B.; Du, J.; Dodge, J.; Li, Y.C.; Chen, X. Targeting Intestinal Vitamin D Receptor Signaling to Mitigate Graft-Versus-Host Disease. Blood 2018, 132, 4515-4515, doi:10.1182/BLOOD-2018-99-117109.

107. Tripkovic, L.; Lambert, H.; Hart, K.; Smith, C.P.; Bucca, G.; Penson, S.; Chope, G.; Hyppönen, E.; Berry, J.; Vieth, R.; et al. Comparison of vitamin D2 and vitamin D3 supplementation in raising serum 25-hydroxyvitamin D status: a systematic review and meta-analysis. Am. J. Clin. Nutr. 2012, 95, 1357-1364, doi:10.3945/ajcn.111.031070.

108. Bischoff-Ferrari, H.A.; Dawson-Hughes, B.; Stöcklin, E.; Sidelnikov, E.; Willett, W.C.; Edel, J.O.; Stähelin, H.B.; Wolfram, S.; Jetter, A.; Schwager, J.; et al. Oral supplementation with 25(OH)D 3 versus vitamin D 3 : Effects on 25(OH)D levels, lower extremity function, blood pressure, and markers of innate immunity. J. Bone Miner. Res. 2012, 27, 160-169, doi:10.1002/jbmr.551.

109. Mazzaferro, S.; Goldsmith, D.; Larsson, T.E.; Massy, Z.A.; Cozzolino, M. Vitamin D Metabolites and/or Analogs: Which D for Which Patient? Curr. Vasc. Pharmacol. 2014, 12, 339-349, doi:10.2174/15701611113119990024.

110. Zand, L.; Kumar, R. The Use of Vitamin D Metabolites and Analogues in the Treatment of Chronic Kidney Disease. Endocrinol. Metab. Clin. North Am. 2017, 46, 983-1007, doi:10.1016/j.ecl.2017.07.008.

111. Hansen, D.; Rasmussen, K.; Danielsen, H.; Meyer-Hofmann, H.; Bacevicius, E.; Lauridsen, T.G.; Madsen, J.K.; Tougaard, B.G.; Marckmann, P.; Thye-Roenn, P.; et al. No difference between alfacalcidol and paricalcitol in the treatment of secondary hyperparathyroidism in hemodialysis patients: a randomized crossover trial. Kidney Int. 2011, 80, 841-850, doi:10.1038/ki.2011.226.

112. Ross, A.C.; Manson, J.E.; Abrams, S.A.; Aloia, J.F.; Brannon, P.M.; Clinton, S.K.; Durazo-Arvizu, R.A.; Gallagher, J.C.; Gallo, R.L.; Jones, G.; et al. The 2011 Report on Dietary Reference Intakes for Calcium and Vitamin D from the Institute of Medicine: What Clinicians Need to Know. J. Clin. Endocrinol. Metab. 2011, 96, 53-58, doi:10.1210/jc.2010-2704.

113. Dawson-Hughes, B.; Mithal, A.; Bonjour, J.-P.; Boonen, S.; Burckhardt, P.; Fuleihan, G.E.-H.; Josse, R.G.; Lips, P.; Morales-Torres, J.; Yoshimura, N. IOF position statement: vitamin D recommendations for older adults. Osteoporos. Int. 2010, 21, 1151-1154, doi:10.1007/s00198-010-1285-3.

114. Lips, P. Vitamin D Deficiency and Secondary Hyperparathyroidism in the Elderly: Consequences for Bone Loss 
and Fractures and Therapeutic Implications. Endocr. Rev. 2001, 22, 477-501, doi:10.1210/edrv.22.4.0437.

115. Giustina, A.; Adler, R.A.; Binkley, N.; Bouillon, R.; Ebeling, P.R.; Lazaretti-Castro, M.; Marcocci, C.; Rizzoli, R.; Sempos, C.T.; Bilezikian, J.P. Controversies in Vitamin D: Summary Statement From an International Conference. J. Clin. Endocrinol. Metab. 2019, 104, 234-240, doi:10.1210/jc.2018-01414.

116. Holick, M.F.; Binkley, N.C.; Bischoff-Ferrari, H.A.; Gordon, C.M.; Hanley, D.A.; Heaney, R.P.; Murad, M.H.; Weaver, C.M. Evaluation, Treatment, and Prevention of Vitamin D Deficiency: an Endocrine Society Clinical Practice Guideline. J. Clin. Endocrinol. Metab. 2011, 96, 1911-1930, doi:10.1210/jc.2011-0385.

117. Heaney, R.P.; Davies, K.M.; Chen, T.C.; Holick, M.F.; Barger-Lux, M.J. Human serum 25-hydroxycholecalciferol response to extended oral dosing with cholecalciferol. Am. J. Clin. Nutr. 2003, 77, 204-210, doi:10.1093/ajen/77.1.204.

118. Varsavsky, M.; Rozas Moreno, P.; Becerra Fernández, A.; Luque Fernández, I.; Quesada Gómez, J.M.; Ávila Rubio, V.; García Martín, A.; Cortés Berdonces, M.; Naf Cortés, S.; Romero Muñoz, M.; et al. Recomendaciones de vitamina D para la población general. Endocrinol. Diabetes y Nutr. 2017, 64, 7-14, doi:10.1016/j.endinu.2016.11.002.

119. Ish-Shalom, S.; Segal, E.; Salganik, T.; Raz, B.; Bromberg, I.L.; Vieth, R. Comparison of Daily, Weekly, and Monthly Vitamin D3 in Ethanol Dosing Protocols for Two Months in Elderly Hip Fracture Patients. J. Clin. Endocrinol. Metab. 2008, 93, 3430-3435, doi:10.1210/jc.2008-0241.

120. Manson, J.E.; Cook, N.R.; Lee, I.-M.; Christen, W.; Bassuk, S.S.; Mora, S.; Gibson, H.; Gordon, D.; Copeland, T.; D'Agostino, D.; et al. Vitamin D Supplements and Prevention of Cancer and Cardiovascular Disease. N. Engl. J. Med. 2019, 380, 33-44, doi:10.1056/NEJMoa1809944.

121. Miyaura, C.; Abe, E.; Kuribayashi, T.; Tanaka, H.; Konno, K.; Nishii, Y.; Suda, T. 1 1 2,25-Dihydroxyvitamin D3 induces differentiation of human myeloid leukemia cells. Biochem. Biophys. Res. Commun. 1981, 102, 937-943, doi:10.1016/0006-291X(81)91628-4.

122. Munker, R.; Norman, A.; Koeffler, H.P. Vitamin D compounds. Effect on clonal proliferation and differentiation of human myeloid cells. J. Clin. Invest. 1986, 78, 424-430, doi:10.1172/JCI112593.

123. Camagna, A.; Testa, U.; Masciulli, R.; Barberi, T.; Samoggia, P.; Tritarelli, E.; Pustorino, E.; Cipollone, L.; Ciancio, L.; del Duca, P.; et al. The synergistic effect of simultaneous addition of retinoic acid and vitamin D3 on the invitro differentiation of human promyelocytic leukemia cell lines could be efficiently transposed in vivo. Med. Hypotheses 1998, 50, 253-257, doi:10.1016/S0306-9877(98)90025-1.

124. Makishima, M.; Shudo, K.; Honma, Y. Greater synergism of retinoic acid receptor (RAR) agonists with vitamin D3 than that of retinoid $X$ receptor (RXR) agonists with regard to growth inhibition and differentiation induction in monoblastic leukemia cells. Biochem. Pharmacol. 1999, 57, 521-529, doi:10.1016/S0006-2952(98)00329-3.

125. Elstner, E.; Linker-Israeli, M.; Umiel, T.; Le, J.; Grillier, I.; Said, J.; Shintaku, I.P.; Krajewski, S.; Reed, J.C.; Binderup, L.; et al. Combination of a potent 20-epi-vitamin D3 analogue (KH 1060) with 9-cis-retinoic acid irreversibly inhibits clonal growth, decreases bcl-2 expression, and induces apoptosis in HL-60 leukemic cells. Cancer Res. 
$1996,56,3570-6$.

126. Elstner, E.; Linker-Israeli, M.; Le, J.; Umiel, T.; Michl, P.; Said, J.W.; Binderup, L.; Reed, J.C.; Koeffler, H.P. Synergistic decrease of clonal proliferation, induction of differentiation, and apoptosis of acute promyelocytic leukemia cells after combined treatment with novel 20-epi vitamin D3 analogs and 9-cis retinoic acid. J. Clin. Invest. 1997, 99, 349-360, doi:10.1172/JCI119164.

127. Hisatake, J.; O’Kelly, J.; Uskokovic, M.R.; Tomoyasu, S.; Koeffler, H.P. Novel vitamin D3 analog, 21-(3-methyl3-hydroxy-butyl)-19-nor D3, that modulates cell growth, differentiation, apoptosis, cell cycle, and induction of PTEN in leukemic cells. Blood 2001, 97, 2427-2433, doi:10.1182/blood.V97.8.2427.

128. Kumagai, T.; Shih, L.-Y.; Hughes, S. V.; Desmond, J.C.; O'Kelly, J.; Hewison, M.; Koeffler, H.P. 19-Nor-1,25(OH) 2 D 2 (a Novel, Noncalcemic Vitamin D Analogue), Combined with Arsenic Trioxide, Has Potent Antitumor Activity against Myeloid Leukemia. Cancer Res. 2005, 65, 2488-2497, doi:10.1158/0008-5472.CAN-04-2800.

129. Müller-Thomas, C.; Tüchler, H.; Rudelius, M.; Schneider, H.; Pfefferkorn, S.; Götze, K.S. Serum Vitamin D Levels in Patients with Myelodysplastic Syndromes: A Retrospective Single-Center Analysis. Acta Haematol. 2019, 141, 225-231, doi:10.1159/000496014.

130. Pardanani, A.; Drake, M.T.; Finke, C.; Lasho, T.L.; Rozell, S.A.; Jimma, T.; Tefferi, A. Vitamin D insufficiency in myeloproliferative neoplasms and myelodysplastic syndromes: Clinical correlates and prognostic studies. Am. J. Hematol. 2011, 86, 1013-1016, doi:10.1002/ajh.22181.

131. Radujkovic, A.; Schnitzler, P.; Ho, A.D.; Dreger, P.; Luft, T. Low serum vitamin D levels are associated with shorter survival after first-line azacitidine treatment in patients with myelodysplastic syndrome and secondary oligoblastic acute myeloid leukemia. Clin. Nutr. 2017, 36, 542-551, doi:10.1016/j.clnu.2016.01.021.

132. Lee, H.J.; Muindi, J.R.; Tan, W.; Hu, Q.; Wang, D.; Liu, S.; Wilding, G.E.; Ford, L.A.; Sait, S.N.J.; Block, A.W.; et al. Low $25(\mathrm{OH})$ vitamin $\mathrm{D} 3$ levels are associated with adverse outcome in newly diagnosed, intensively treated adult acute myeloid leukemia. Cancer 2014, 120, 521-529, doi:10.1002/cncr.28368.

133. Koeffler, H.P.; Hirji, K.; Itri, L. 1,25-Dihydroxyvitamin D3: in vivo and in vitro effects on human preleukemic and leukemic cells. Cancer Treat. Rep. 1985, 69, 1399-407.

134. Mellibovsky; Díez; Pérez-Vila; Serrano; Nacher; AubÍa; Supervía; Recker, R.R. Vitamin D treatment in myelodysplastic syndromes. Br. J. Haematol. 1998, 100, 516-520, doi:10.1046/j.1365-2141.1998.00598.x.

135. Koeffler, H.P.; Aslanian, N.; O'Kelly, J. Vitamin D2 analog (Paricalcitol; Zemplar) for treatment of myelodysplastic syndrome. Leuk. Res. 2005, 29, 1259-1262, doi:10.1016/j.leukres.2005.04.003.

136. Petrich, A.; Kahl, B.; Bailey, H.; Kim, K.; Turman, N.; Juckett, M. Phase II study of doxercalciferol for the treatment of myelodysplastic syndrome. Leuk. Lymphoma 2008, 49, 57-61, doi:10.1080/10428190701713648.

137. Motomura, S.; Kanamori, H.; Ohkubo, T.; Maruta, A.; Kodama, F. The effect of 1-hydroxyvitamin D3 for prolongation of leukemic transformation-free survival in myelodysplastic syndromes. Am. J. Hematol. 1991, 38, 67-68, doi:10.1002/ajh.2830380112. 
138. Akiyama, N.; Miyazawa, K.; Kanda, Y.; Tohyama, K.; Omine, M.; Mitani, K.; Ohyashiki, K. Multicenter phase II trial of vitamin K2 monotherapy and vitamin K2 plus 1 $\alpha$-hydroxyvitamin D3 combination therapy for low-risk myelodysplastic syndromes. Leuk. Res. 2010, 34, 1151-1157, doi:10.1016/j.leukres.2010.04.006.

139. Hellström, E.; Robert, K.-H.; Samuelsson, J.; Lindemalm, C.; Grimfors, G.; Kimby, E.; Öberg, G.; Winqvist, I.; Billström, R.; Carneskog, J.; et al. Treatment of myelodysplastic syndromes with retinoic acid and $1 \alpha$-hydroxyvitamin D3 in combination with low-dose ara-C is not superior to ara-C alone. Results from a randomized study. Eur. J. Haematol. 2009, 45, 255-261, doi:10.1111/j.1600-0609.1990.tb00470.x.

140. Ferrero, D.; Darbesio, A.; Giai, V.; Genuardi, M.; Dellacasa, C.M.; Sorasio, R.; Bertini, M.; Boccadoro, M. Efficacy of a combination of human recombinant erythropoietin + 13- cis -retinoic acid and dihydroxylated vitamin D3 to improve moderate to severe anaemia in low/intermediate risk myelodysplastic syndromes. Br. J. Haematol. 2009, 144, 342-349, doi:10.1111/j.1365-2141.2008.07465.x.

141. Slapak, C.A.; Desforges, J.F.; Fogaren, T.; Miller, K.B. Treatment of acute myeloid leukemia in the elderly with low-dose cytarabine, hydroxyurea, and calcitriol. Am. J. Hematol. 1992, 41, 178-183, doi:10.1002/ajh.2830410307.

142. Tracy, S.I.; Maurer, M.J.; Witzig, T.E.; Drake, M.T.; Ansell, S.M.; Nowakowski, G.S.; Thompson, C.A.; Inwards, D.J.; Johnston, P.B.; Micallef, I.N.; et al. Vitamin D insufficiency is associated with an increased risk of early clinical failure in follicular lymphoma. Blood Cancer J. 2017, 7, e595-e595, doi:10.1038/bcj.2017.70.

143. Kelly, J.L.; Salles, G.; Goldman, B.; Fisher, R.I.; Brice, P.; Press, O.; Casasnovas, O.; Maloney, D.G.; Soubeyran, P.; Rimsza, L.; et al. Low Serum Vitamin D Levels Are Associated With Inferior Survival in Follicular Lymphoma: A Prospective Evaluation in SWOG and LYSA Studies. J. Clin. Oncol. 2015, 33, 1482-1490, doi:10.1200/JCO.2014.57.5092.

144. Drake, M.T.; Maurer, M.J.; Link, B.K.; Habermann, T.M.; Ansell, S.M.; Micallef, I.N.; Kelly, J.L.; Macon, W.R.; Nowakowski, G.S.; Inwards, D.J.; et al. Vitamin D Insufficiency and Prognosis in Non-Hodgkin's Lymphoma. J. Clin. Oncol. 2010, 28, 4191-4198, doi:10.1200/JCO.2010.28.6674.

145. Park, H.Y.; Hong, Y.-C.; Lee, K.; Koh, J. Vitamin D status and risk of non-Hodgkin lymphoma: An updated metaanalysis. PLoS One 2019, 14, e0216284, doi:10.1371/journal.pone.0216284.

146. Xu, D.; Liang, J.; Wang, L.; Zhu, H.-Y.; Xia, Y.; Fan, L.; Li, J.-Y.; Xu, W. 25-Hydroxy vitamin D deficiency predicts inferior prognosis in mantle cell lymphoma. J. Cancer Res. Clin. Oncol. 2020, 146, 1003-1009, doi:10.1007/s00432020-03125-w.

147. Qin, J.-Q.; Yin, H.; Wu, J.-Z.; Chen, R.-Z.; Xia, Y.; Wang, L.; Zhu, H.-Y.; Fan, L.; Li, J.-Y.; Liang, J.-H.; et al. 25Hydroxy vitamin D deficiency predicts inferior prognosis in Hodgkin lymphoma. Leuk. Res. 2021, 105, 106580, doi:10.1016/j.leukres.2021.106580.

148. Hohaus, S.; Tisi, M.C.; Bellesi, S.; Maiolo, E.; Alma, E.; Tartaglia, G.; Corrente, F.; Cuccaro, A.; D’ Alo', F.; Basile, U.; et al. Vitamin D deficiency and supplementation in patients with aggressive B-cell lymphomas treated with immunochemotherapy. Cancer Med. 2018, 7, 270-281, doi:10.1002/cam4.1166.

149. Ammann, E.M.; Drake, M.T.; Haraldsson, B.; Wallace, R.B.; Johnson, K.C.; Desai, P.; Lin, E.M.; Link, B.K. 
Incidence of hematologic malignancy and cause-specific mortality in the Women's Health Initiative randomized controlled trial of calcium and vitamin D supplementation. Cancer 2017, 123, 4168-4177, doi:10.1002/cncr.30858.

150. Sfeir, J.G.; Drake, M.T.; LaPlant, B.R.; Maurer, M.J.; Link, B.K.; Berndt, T.J.; Shanafelt, T.D.; Cerhan, J.R.; Habermann, T.M.; Feldman, A.L.; et al. Validation of a vitamin D replacement strategy in vitamin D-insufficient patients with lymphoma or chronic lymphocytic leukemia. Blood Cancer J. 2017, 7, e526-e526, doi:10.1038/bcj.2017.9.

151. Puthier, D.; Bataille, R.; Barillé, S.; Mellerin, M.P.; Harousseau, J.L.; Ponzio, A.; Robillard, N.; Wijdenes, J.; Amiot, M. Myeloma cell growth arrest, apoptosis, and interleukin-6 receptor modulation induced by EB1089, a vitamin D3 derivative, alone or in association with dexamethasone. Blood 1996, 88, 4659-66.

152. Park, W.H.; Seol, J.G.; Kim, E.S.; Binderup, L.; Koeffler, H.P.; Kim, B.K.; Lee, Y.Y. The induction of apoptosis by a combined 1,25(OH)2D3 analog, EB1089 and TGF-beta1 in NCI-H929 multiple myeloma cells. Int. J. Oncol. 2002, $20,533-42$.

153. Burwick, N. Vitamin D and plasma cell dyscrasias: reviewing the significance. Ann. Hematol. 2017, 96, 1271-1277, doi:10.1007/s00277-017-3016-8.

154. Simmons, J.; Sheedy, C.; Lee, H.; Koh, S.; Alvarez, J.; Koyama, T.; Friedman, D. Prevalence of 25-hydroxyvitamin $\mathrm{D}$ deficiency in child and adolescent patients undergoing hematopoietic cell transplantation compared to a healthy population. Pediatr. Blood Cancer 2013, 60, 2025-2030, doi:10.1002/pbc.24684.

155. Kenny, S.A.; Collum, K.; Featherstone, C.A.; Farooki, A.; Jakubowski, A. Impact of a Replacement Algorithm for Vitamin D Deficiency in Adult Hematopoietic Stem Cell Transplant Patients. J. Adv. Pract. Oncol. 2019, 10, 109118.

156. Martinez-Cibrian, N.; Zeiser, R.; Perez-Simon, J.A. Graft-versus-host disease prophylaxis: Pathophysiologybased review on current approaches and future directions. Blood Rev. 2020, 100792.

157. MacDonald, K.P.A.A.; Hill, G.R.; Blazar, B.R. Chronic graft-versus-host disease: biological insights from preclinical and clinical studies. Blood 2017, 129, 13-21, doi:10.1182/blood-2016-06-686618.

158. Cooke, K.R.; Luznik, L.; Sarantopoulos, S.; Hakim, F.T.; Jagasia, M.; Fowler, D.H.; van den Brink, M.R.M.; Hansen, J.A.; Parkman, R.; Miklos, D.B.; et al. The Biology of Chronic Graft-versus-Host Disease: A Task Force Report from the National Institutes of Health Consensus Development Project on Criteria for Clinical Trials in Chronic Graft-versus-Host Disease. Biol. Blood Marrow Transplant. 2017, 23, 211-234, doi:10.1016/j.bbmt.2016.09.023.

159. Zeiser, R.; Blazar, B.R. Pathophysiology of chronic graft-versus-host disease and therapeutic targets. N. Engl. J. Med. 2017, 377, 2565-2579, doi:10.1056/NEJMra1703472.

160. Urbain, P.; Ihorst, G.; Biesalski, H.-K.; Bertz, H. Course of serum 25-hydroxyvitamin D3 status and its influencing factors in adults undergoing allogeneic hematopoietic cell transplantation. Ann. Hematol. 2012, 91, 759-766, doi:10.1007/s00277-011-1365-2.

161. Wallace, G.; Jodele, S.; Howell, J.; Myers, K.C.; Teusink, A.; Zhao, X.; Setchell, K.; Holtzapfel, C.; Lane, A.; Taggart, 
C.; et al. Vitamin D Deficiency and Survival in Children after Hematopoietic Stem Cell Transplant. Biol. Blood Marrow Transplant. 2015, 21, 1627-1631, doi:10.1016/j.bbmt.2015.06.009.

162. Dahir, K.; Perry, B.; Jagasia, S. Post-Transplantation Bone Disease: Prevalence, Monitoring, Prevention, and Management Guidelines. In Blood and Marrow Transplantation Long-Term Management; John Wiley \& Sons, Ltd: Oxford, UK, 2013; pp. 151-161.

163. Jabbour, J.; Manana, B.; Zahreddine, A.; Al-Shaar, L.; Bazarbachi, A.; Blaise, D.; El-Cheikh, J. Vitamins and minerals intake adequacy in hematopoietic stem cell transplant: results of a randomized controlled trial. Bone Marrow Transplant. 2021, 56, 1106-1115, doi:10.1038/s41409-020-01154-0.

164. Kreutz, M.; Eissner, G.; Hahn, J.; Andreesen, R.; Drobnik, W.; Holler, E. Variations in 1 1 2 ,25-dihydroxyvitamin D3 and 25-hydroxyvitamin D3 serum levels during allogeneic bone marrow transplantation. Bone Marrow Transplant. 2004, 33, 871-873, doi:10.1038/sj.bmt.1704448.

165. Glotzbecker, B.; Ho, V.T.; Aldridge, J.; Kim, H.T.; Horowitz, G.; Ritz, J.; Soiffer, R.; Avigan, D.; Rosenblatt, J. Low levels of 25-hydroxyvitamin D before allogeneic hematopoietic SCT correlate with the development of chronic GVHD. Bone Marrow Transplant. 2013, 48, 593-597, doi:10.1038/bmt.2012.177.

166. Ganetsky, A.; Richman, L.P.; Frey, N. V.; Vonderheide, R.H.; Porter, D.L.; Reshef, R. Vitamin D Deficiency Predicts Acute Cutaneous Graft-Versus-Host Disease in Reduced-Intensity Allogeneic Hematopoietic Stem Cell Transplantation. Biol. Blood Marrow Transplant. 2014, 20, S267-S268, doi:10.1016/j.bbmt.2013.12.451.

167. Hansson, M.E.A.; Norlin, A.-C.; Omazic, B.; Wikström, A.-C.; Bergman, P.; Winiarski, J.; Remberger, M.; Sundin, M. Vitamin D Levels Affect Outcome in Pediatric Hematopoietic Stem Cell Transplantation. Biol. Blood Marrow Transplant. 2014, 20, 1537-1543, doi:10.1016/j.bbmt.2014.05.030.

168. von Bahr, L.; Blennow, O.; Alm, J.; Björklund, A.; Malmberg, K.-J.; Mougiakakos, D.; Le Blanc, A.; Oefner, P.J.; Labopin, M.; Ljungman, P.; et al. Increased incidence of chronic GvHD and CMV disease in patients with vitamin D deficiency before allogeneic stem cell transplantation. Bone Marrow Transplant. 2015, 50, 1217-1223, doi:10.1038/bmt.2015.123.

169. Campos, D.J.; Biagini, G.L.K.; Funke, V.A.M.; Bonfim, C.M.S.; Boguszewski, C.L.; Borba, V.Z.C. Vitamin D deficiency in children and adolescents submitted to hematopoietic stem cell transplantation. Rev. Bras. Hematol. Hemoter. 2014, 36, 126-31, doi:10.5581/1516-8484.20140029.

170. Beebe, K.; Magee, K.; McNulty, A.; Stahlecker, J.; Salzberg, D.; Miller, H.; Mirea, L.; Adams, R.; Ngwube, A. Vitamin D deficiency and outcomes in pediatric hematopoietic stem cell transplantation. Pediatr. Blood Cancer 2018, 65, e26817, doi:10.1002/pbc.26817.

171. Robien, K.; Strayer, L.G.; Majhail, N.; Lazovich, D.; Baker, K.S.; Smith, A.R.; Mulrooney, D.A.; Burns, L.J. Vitamin D status among long-term survivors of hematopoietic cell transplantation. Bone Marrow Transplant. 2011, 46, 1472-1479, doi:10.1038/bmt.2010.326.

172. Bajwa, R.P.S.; Taylor, K.; Hoyt, A.; Kamboj, M.K.; Stanek, J.; Mahadeo, K.M.; Alsaedi, H.; Abdel-Azim, H.; O'Kane, S.; Martin, P.L.; et al. Vitamin D has no impact on outcomes after HSCT in children-A retrospective 
study. Pediatr. Transplant. 2021, 25, doi:10.1111/petr.14008.

173. Katić, M.; Pirsl, F.; Steinberg, S.M.; Dobbin, M.; Curtis, L.M.; Pulanić, D.; Desnica, L.; Titarenko, I.; Pavletic, S.Z. Vitamin $\mathrm{D}$ levels and their associations with survival and major disease outcomes in a large cohort of patients with chronic graft-vs-host disease. Croat. Med. J. 2016, 57, 276-286, doi:10.3325/cmj.2016.57.276.

174. Bhandari, R.; Malvar, J.; Sacapano, A.; Aguayo-Hiraldo, P.; Jodele, S.; Orgel, E. Association between Vitamin D and Risk for Early and Late Post-Transplant Complications. Biol. Blood Marrow Transplant. 2020, 26, 343-350, doi:10.1016/j.bbmt.2019.10.011.

175. Perera, T.; Ming Lim, A.B.; Mason, K.; Szer, J.; Ritchie, D.S. The Relationship Between Pre-Transplant 25Hydroxy-Vitamin D Levels, Survival and Graft-Versus-Host Disease, in Allogeneic Haematopoietic Stem Cell Transplantation. Biol. Blood Marrow Transplant. 2015, 21, S303, doi:10.1016/j.bbmt.2014.11.482.

176. Radujkovic, A.; Kordelas, L.; Krzykalla, J.; Beelen, D.W.; Benner, A.; Lehners, N.; Schmidt, K.; Dreger, P.; Luft, T. Pretransplant Vitamin D Deficiency Is Associated With Higher Relapse Rates in Patients Allografted for Myeloid Malignancies. J. Clin. Oncol. 2017, 35, 3143-3152, doi:10.1200/JCO.2017.73.0085.

177. Peter, K.; Siska, P.J.; Roider, T.; Matos, C.; Bruns, H.; Renner, K.; Singer, K.; Weber, D.; Güllstorf, M.; Kröger, N.; et al. 1,25-dihydroxyvitamin-D3 but not the clinically applied marker 25-hydroxyvitamin-D3 predicts survival after stem cell transplantation. Bone Marrow Transplant. 2021, 56, 419-433, doi:10.1038/s41409-020-01031-w.

178. ITO, Y.; Honda, A.; Kurokawa, M. Impact of vitamin D level at diagnosis and transplantation on the prognosis of hematological malignancy: a meta-analysis. Blood Adv. 2021, doi:10.1182/bloodadvances.2021004958.

179. Chiengthong, K.; Cheungpasitporn, W.; Thongprayoon, C.; Lertjitbanjong, P.; Cato, L.D.; Bathini, T.; Ungprasert, P.; Mao, M.A.; Chokesuwattanaskul, R. Vitamin D deficiency is not associated with graft versus host disease after hematopoietic stem cell transplantation: A meta-analysis. J. Evid. Based. Med. 2020, 13, 183-191, doi:10.1111/jebm.12383.

180. Ros-Soto, J.; Anthias, C.; Madrigal, A.; Snowden, J.A. Vitamin D: is it important in haematopoietic stem cell transplantation? A review. Bone Marrow Transplant. 2019, 54, 810-820, doi:10.1038/s41409-018-0377-0.

181. Silva, F.; Pérez-Simón, J.A.; Caballero-Velazquez, T.; Sánchez-Guijo, F.M.; Villanueva-Gomez, F.; Vazquez, L.; del Cañizo, C.; Caballero, D.; San Miguel, J. Effect of vitamin D treatment in chronic GVHD. Bone Marrow Transplant. 2011, 46, 1395-1397, doi:10.1038/bmt.2010.317.

182. Bhandari, R.; Aguayo-Hiraldo, P.; Malvar, J.; Cheng, K.; Sacapano, A.; Abdel-Azim, H.; Chi, Y.-Y.; Wallace, G.; Asgharzadeh, S.; Jodele, S.; et al. Ultra-High Dose Vitamin D in Pediatric Hematopoietic Stem Cell Transplantation: A Nonrandomized Controlled Trial. Transplant. Cell. Ther. 2021, 27, 1001.e1-1001.e9, doi:10.1016/j.jtct.2021.08.030.

183. Carrillo-Cruz, E.; García-Lozano, J.R.; Márquez-Malaver, F.J.; Sánchez-Guijo, F.M.; Montero Cuadrado, I.; Ferra i Coll, C.; Valcárcel, D.; López-Godino, O.; Cuesta, M.; Parody, R.; et al. Vitamin D Modifies the Incidence of Graft-versus-Host Disease after Allogeneic Stem Cell Transplantation Depending on the Vitamin D Receptor (VDR) Polymorphisms. Clin. Cancer Res. 2019, 25, 4616-4623, doi:10.1158/1078-0432.CCR-18-3875. 
184. Caballero-Velazquez, T.; Montero, I.; Sanchez-Guijo, F.; Parody, R.; Saldana, R.; Valcarcel, D.; Lopez-Godino, O.; Ferra i Coll, C.; Cuesta, M.; Carrillo-Vico, A.; et al. Immunomodulatory Effect of Vitamin D after Allogeneic Stem Cell Transplantation: Results of a Prospective Multicenter Clinical Trial. Clin. Cancer Res. 2016, 22, 5673-5681, doi:10.1158/1078-0432.CCR-16-0238.

185. Siitonen, T.; Timonen, T.; Juvonen, E.; Terava, V.; Kutila, A.; Honkanen, T.; Mikkola, M.; Hallman, H.; Kauppila, M.; Nylanden, P.; et al. Valproic acid combined with 13-cis retinoic acid and 1,25-dihydroxyvitamin D3 in the treatment of patients with myelodysplastic syndromes. Haematologica 2007, 92, 1119-1122, doi:10.3324/haematol.11262.

186. Gjærde, L.K.; Ostrowski, S.R.; Andersen, N.S.; Friis, L.S.; Kornblit, B.; Petersen, S.L.; Schjødt, I.; Sengeløv, H. Pretransplantation plasma vitamin D levels and acute graft-versus-host disease after myeloablative hematopoietic cell transplantation in adults. Transpl. Immunol. 2021, 68, 101437, doi:10.1016/j.trim.2021.101437.

187. Wallace, G.; Jodele, S.; Myers, K.C.; Dandoy, C.E.; El-Bietar, J.; Nelson, A.; Teusink-Cross, A.; Khandelwal, P.; Taggart, C.; Gordon, C.M.; et al. Single Ultra-High-Dose Cholecalciferol to Prevent Vitamin D Deficiency in Pediatric Hematopoietic Stem Cell Transplantation. Biol. Blood Marrow Transplant. 2018, 24, 1856-1860, doi:10.1016/j.bbmt.2018.05.019.

188. Duncan, C.N.; Vrooman, L.; Apfelbaum, E.M.; Whitley, K.; Bechard, L.; Lehmann, L.E. 25-Hydroxy Vitamin D Deficiency Following Pediatric Hematopoietic Stem Cell Transplant. Biol. Blood Marrow Transplant. 2011, 17, 749753, doi:10.1016/j.bbmt.2010.10.009.

189. Wallace, G.; Jodele, S.; Myers, K.C.; Dandoy, C.E.; El-Bietar, J.; Nelson, A.; Taggart, C.B.; Daniels, P.; Lane, A.; Howell, J.; et al. Vitamin D Deficiency in Pediatric Hematopoietic Stem Cell Transplantation Patients Despite Both Standard and Aggressive Supplementation. Biol. Blood Marrow Transplant. 2016, 22, 1271-1274, doi:10.1016/j.bbmt.2016.03.026. 
Table 1. Interventional studies evaluating the efficacy of vitamin D administration in hematologic malignancies.

\begin{tabular}{|c|c|c|c|c|c|}
\hline & Study & $\mathbf{N}$ & Intervention & $\begin{array}{c}\text { Vit D levels } \\
\text { Median/range }\end{array}$ & Endpoints \\
\hline $\begin{array}{c}\text { MDS } \\
\text { Koeffler et al. } \\
1985[133]\end{array}$ & NR & 18 & Calcitriol $>2 \mathrm{mcg}$ & ---- & MR and PR: $44 \%(8 / 18)$ \\
\hline $\begin{array}{c}\text { MDS } \\
\text { Motomura et al, } \\
1991[137]\end{array}$ & $\begin{array}{l}\text { Phase } \\
\text { II }\end{array}$ & 30 & $\begin{array}{c}\text { Alfalcidol 4-6 mcg/day } \\
\text { vs no therapy }\end{array}$ & --- & $\begin{array}{c}\text { Progression to AML: } \\
\text { - Alfacalcidol: } 6 \%(1 / 15) \\
\text { - No therapy: } 46.6 \%(7 / 15)\end{array}$ \\
\hline $\begin{array}{c}\text { MDS } \\
\text { IPSS low and high } \\
\text { Koeffler et al, } \\
2005[135]\end{array}$ & NR & 12 & $\begin{array}{c}\text { Paricalcitol } 8 \mu \mathrm{g} / \mathrm{day} \text { and } \\
\text { increments of } 8 \mu \mathrm{g} / \text { day } \\
\text { every } 2 \text { weeks }\end{array}$ & ---- & $\begin{array}{l}\text { OR: } 0 \% .1 / 12 \text { patient's plate- } \\
\text { let count achieved normal } \\
\text { range for } 5 \text { weeks. }\end{array}$ \\
\hline $\begin{array}{l}\text { MDS and CMML } \\
\text { IPSS low-int1 } \\
\text { Mellibovsky et al, } \\
2001[134]\end{array}$ & NR & 19 & $\begin{array}{c}\text { - Calcifediol } 266 \text { mcg } 3 \\
\text { times a week. } \mathrm{N}=5 \text {. } \\
\text { - Calcitriol } 0.25-0.75 \\
\text { mcg/d N=14 }\end{array}$ & $\begin{array}{l}\text { Increased from } \\
9.4 \pm 4.6 \mathrm{ng} / \mathrm{ml} \\
\text { to } 37.5 \pm 44.2 \\
\quad(\mathrm{p}=0.003)\end{array}$ & $\begin{array}{c}\text { OR: 57\% (11/19) } \\
\text { No hypercalcemia }\end{array}$ \\
\hline $\begin{array}{c}\text { MDS an CMML } \\
\text { Petrich et al, } \\
2008[136]\end{array}$ & $\begin{array}{c}\text { Phase } \\
\text { II }\end{array}$ & 15 & $\begin{array}{c}\text { Doxercalciferol } 12.5 \\
\text { mcg/day for } 12 \text { weeks. }\end{array}$ & --- & No responses \\
\hline $\begin{array}{l}\text { MDS with IPSS } \\
\text { low and int-1 } \\
\text { Akiyama et al, } \\
2010[138]\end{array}$ & $\begin{array}{l}\text { Phase } \\
\text { II }\end{array}$ & 20 & $\begin{array}{l}\text { Alfacalcidol } 0.75 \mathrm{mcg} / \mathrm{day} \\
+45 \mathrm{mg} \text { of menatetrenone } \\
\text { for } 1 \text { year if response }\end{array}$ & --- & ORR was 30\% (6/20) \\
\hline $\begin{array}{l}\text { MDS and AML } \\
\text { Hellström et al, } \\
2009 \text { [139] }\end{array}$ & $\begin{array}{l}\text { Phase } \\
\text { III }\end{array}$ & $\begin{array}{l}63 \\
\text { MDS } \\
15 \\
\text { AML }\end{array}$ & $\begin{array}{l}\text { Arm 1: Ld ara-C vs } \\
\text { Arm 2: Ld ara-C + 13- } \\
\text { CRA and Alfacalcidol }\end{array}$ & --- & $\begin{array}{c}\text { Similar OS, ORR or DOR. } \\
\text { Progressed from } \\
\text { MDS to AML: } \\
44 \% \text { vs } 20 \%(\mathrm{p}=0.0527)\end{array}$ \\
\hline $\begin{array}{l}\text { MDS } \\
\text { IPSS low-int-2 } \\
\text { Ferrero et al, }\end{array}$ & $\begin{array}{l}\text { Phase } \\
\text { II }\end{array}$ & 63 & $\begin{array}{l}\mathrm{EPO}+13-\mathrm{CRA}+ \\
\text { Calcitriol }\end{array}$ & --- & $\begin{array}{r}\text { RAEB1 OS } 14 \text { months } \\
\text { Non-RAEB1 OS } 55 \text { months } \\
\text { Erythroid response: } 60 \%\end{array}$ \\
\hline
\end{tabular}




\begin{tabular}{|c|c|c|c|c|c|}
\hline $2008[140]$ & & & & & (93\% in low risk patients) \\
\hline $\begin{array}{l}\text { MDS and CMML } \\
\text { Siitonen et al, } \\
2007[185]\end{array}$ & NR & 19 & $\begin{array}{l}\text { Valproic acid (dose ad- } \\
\text { justed by levels) + } \\
\text { 13-CRA (10mg/12h) + Cal- } \\
\text { citriol (1mcg) }\end{array}$ & --- & $\begin{array}{l}\text { Blood improvement: } \\
\text { 3/19 patients (16\%). } \\
\text { 8/19 discontinued (side ef- } \\
\text { fects, no hypercalcemia). }\end{array}$ \\
\hline $\begin{array}{l}\text { AML (elderly) } \\
\text { Slapak et al, } \\
1992[141]\end{array}$ & NR & 29 & $\begin{array}{c}\text { - Ld Ara-C + } \\
\text { Hydroxyurea }+ \\
\text { calcitriol }(0.5 \mu \mathrm{g} / 12 \mathrm{~h})\end{array}$ & --- & $\begin{array}{c}\text { ORR 79\% } \\
\text { CR } 45 \% \text { / PR 34\% } \\
\text { DOR: } 9,8 \text { months }\end{array}$ \\
\hline $\begin{array}{l}\text { MDS IPSS 0/I } \\
\text { NCT00068276 } \\
\text { (Ongoing) }\end{array}$ & $\begin{array}{l}\text { Phase } \\
\text { II }\end{array}$ & 36 & $\begin{array}{c}\text { Cholecalciferol } \\
\text { Doses not specified }\end{array}$ & & Safety and efficacy \\
\hline $\begin{array}{c}\text { CLL } \\
\text { NCT01518959 } \\
\text { (Ongoing) }\end{array}$ & $\begin{array}{l}\text { Phase } \\
\text { III }\end{array}$ & 31 & $\begin{array}{c}\text { Cholecalciferol } \\
\text { (180.000 IU monthly) } \\
\text { vs placebo }\end{array}$ & & $\begin{array}{c}\text { 5-year OS , PFS, TTF } \\
\text { 5-year lymphocyte count }\end{array}$ \\
\hline $\begin{array}{l}\text { Aggressive NHL } \\
\text { Hohaus et al, } \\
2018 \text { [148] }\end{array}$ & NR & 155 & $\begin{array}{l}\text { - Cholecalciferol } \\
\text { loading phase: } \\
\text { 25000 IU daily } \\
\text { maintenance phase: } \\
\text { 25,000 IU weekly }\end{array}$ & $\begin{array}{c}\text { Vitamin D } \\
\text { Pre-treatment } \\
14 \pm 1.4 \mathrm{ng} / \mathrm{mL} \\
\text { post-treatment } \\
33 \pm 1.4(\mathrm{n}=81) \\
(\mathrm{p}<0.0001)\end{array}$ & $\begin{array}{l}\text { Independent prognostic pa- } \\
\text { rameters for EFS: } \\
-25(\mathrm{OH}) \mathrm{D} \text { levels }<20 \mathrm{ng} / \mathrm{ml} \\
\text { HR } 2.88 \mathrm{p}<0.02 . \\
\text { - IPI HR } 2.97 \mathrm{p}<0.002 . \\
\text { No hypercalcemia }\end{array}$ \\
\hline $\begin{array}{l}\text { NHL and CLL } \\
\text { Sfeir et al, } \\
2017 \text { [150] } \\
\text { NCT01787409 }\end{array}$ & $\begin{array}{l}\text { Phase } \\
\text { I/II }\end{array}$ & 158 & $\begin{array}{l}\text { Cholecalciferol } 50.000 \mathrm{IU} \\
\text { weekly, } 12 \text { weeks } \\
\text { If }<30 \mathrm{ng} / \mathrm{ml}: \\
50.000 \mathrm{IU} \text { twice weekly } \\
\text { When } \geqslant 30 \mathrm{ng} / \mathrm{ml}: \\
50.000 \mathrm{IU} / \mathrm{month}\end{array}$ & $\begin{array}{c}{ }^{*} \text { Vitamin } \mathrm{D} \\
\text { deficiency } 45 \% \\
(\mathrm{n}=71) \\
\text { Mean } \pm \text { SEM } \\
17 \pm 5 \mathrm{ng} / \mathrm{ml}\end{array}$ & $\begin{array}{c}97 \% \text { of vitamin } \mathrm{D} \\
\text { insufficient group reached } \\
\text { levels } \geqslant 30 \mathrm{ng} / \mathrm{ml} \text { prior to fol- } \\
\text { low-up period of } 3 \text { years, } \\
\text { during which these levels are } \\
\text { maintained }\end{array}$ \\
\hline $\begin{array}{l}\text { NHL and CLL } \\
\text { NCT01787409 } \\
\text { (Ongoing) }\end{array}$ & $\begin{array}{l}\text { Phase } \\
\text { I/II }\end{array}$ & 713 & $\begin{array}{l}\text { Cholecalciferol PO once } \\
\text { weekly for } 12 \text { weeks and } \\
\text { then once monthly for a } \\
\text { total of } 36 \text { months }\end{array}$ & --- & $\begin{array}{c}\text { 12-month EFS } \\
\text { 36-month Treatment free } \\
\text { 5-year ORR, OS } \\
\text { 5-year TTF (CLL patients) }\end{array}$ \\
\hline $\begin{array}{l}\text { NHL and CLL } \\
\text { NCT02553447 } \\
\text { (Ongoing) }\end{array}$ & $\begin{array}{l}\text { Early } \\
\text { phase } \\
\text { I }\end{array}$ & 370 & $\begin{array}{l}{ }^{*} \text { Arm I: high-dose } \\
\text { cholecalciferol PO daily } \\
{ }^{*} \text { Arm II: low-dose } \\
\text { cholecalciferol PO daily } \\
{ }^{*} \text { Arm III (control) }\end{array}$ & --- & $\begin{array}{l}\text { 3-years PFS } \\
\text { 3-years OS }\end{array}$ \\
\hline $\begin{array}{l}\text { Indolent NHL } \\
\text { (Clinical trial } \\
\text { ILyAD) } \\
\text { NCT03078855 } \\
\text { (Ongoing) }\end{array}$ & $\begin{array}{l}\text { Phase } \\
\text { III }\end{array}$ & 210 & $\begin{array}{l}\text { Weekly Rituximab x } 4+ \\
\text { * Arm 1: Cholecalciferol } \\
\text { 2.000 IU daily } \\
\text { * Arm 2: Placebo }\end{array}$ & --- & $\begin{array}{l}\text { 3-years PFS and OS } \\
\text { Response to rituximab (re- } \\
\text { duction of lymphoma bur- } \\
\text { den by at least } 50 \% \text { ) }\end{array}$ \\
\hline $\begin{array}{c}\text { Diffuse Large B } \\
\text { Cell Lymphoma } \\
\text { (65 years and older) } \\
\text { (FIL_PREVID) } \\
\text { NCT04442412 } \\
\text { (Ongoing) }\end{array}$ & $\begin{array}{l}\text { Phase } \\
\text { III }\end{array}$ & 430 & $\begin{array}{c}{ }^{*} \text { Arm A: } 7 \text { days of oral } \\
\text { prednisone prephase } \\
{ }^{*} \text { Arm B: } 7 \text { days of oral } \\
\text { prednisone and } \\
\text { cholecalciferol }(25.000 \\
\text { IU/day) prephase. } \\
\text { Then } 25.000 \text { IU/week } \\
\text { * Both followed by } 6 \\
\text { courses of R-CHOP } \\
\text { R-miniCHOP/21 days }\end{array}$ & --- & $\begin{array}{l}\text { 54-months PFS, OS, EFS, 54- } \\
\text { months RR, EDR } \\
\text { 54-months Rate of ECOG } \\
\text { changes after prephase } \\
\text { Rate of patient with } \\
\text { 25(OH)VitD levels } \\
\text { correction at cycle } 2 \\
\text { Time-to-deterioration physi- } \\
\text { cal functioning and fatigue at } \\
\text { cycle } 2 \text {. }\end{array}$ \\
\hline
\end{tabular}




\begin{tabular}{ccccc}
\hline Untreated Early & Phase & 35 & Curcumin + oral daily & ORR, TTNT \\
Stage CLL (or SLL) & II & & cholecalciferol on days 1- \\
(Ongoing) & & 28, for 6 cycles. If PR, & 2 years PFS, OS \\
& & treatment up to 2 years. & 2 years DOR
\end{tabular}

NR: not reported; PFS: progression free survival; OS: overall survival; EFS: event free survival; PFS: progression free survival; RR: response rate; ORR: overall response rate; PR: partial response; MR: minor response. DOR duration of response; EDR: early death rate; TTF: time to first treatment; TTNT: time to next treatment; CLL: chronic lymphocytic leukemia; SLL: Small Lymphocytic Lymphoma. Ld: low dose. SEM: Standard error of the mean. Int-1: intermediate 1. MDS: myelodysplastic syndrome. CMML: chronic myelomonocytic leukemia. NHL: non-Hodgkin Lymphoma. 13-CRA: 13-cis-retinoic acid 
Table 2: Relationship between vitamin D levels and main outcomes after allo-HSCT.

\begin{tabular}{|c|c|c|c|c|c|c|}
\hline & \multirow[t]{2}{*}{ Study } & \multirow[t]{2}{*}{$\mathbf{N}$} & \multicolumn{2}{|c|}{$\begin{array}{l}\text { Vitamin D levels } \\
\text { Median +/- 2 S.D }\end{array}$} & \multirow[t]{2}{*}{ Impact on GVHD } & \multirow[t]{2}{*}{$\begin{array}{l}\text { Survival and } \\
\text { Other endpoints }\end{array}$} \\
\hline & & & Pre-Allo & Post-Allo & & \\
\hline $\begin{array}{l}\text { Kreutz et al, } \\
2004[164]\end{array}$ & Prospective & 48 & $\begin{array}{c}36.4 \pm 2.2 \\
\mathrm{nmol} / \mathrm{L}\end{array}$ & $\begin{array}{c}\downarrow \text { compared to } \\
\text { Pre-allo: } 27.8 \pm 1.3 \mathrm{nmol} / \mathrm{L} .\end{array}$ & $\begin{array}{l}\text { In patients with grades 3-4 GvHD } \\
\text { serum levels remained low/dropped }\end{array}$ & \\
\hline $\begin{array}{l}\text { Glotzbecker } \\
\text { et al, 2013 } \\
{[165]}\end{array}$ & Retrospective & 53 & $\begin{array}{c}21.9 \mathrm{ng} / \mathrm{mL} \\
(7.8-45.7) \\
\text { Vitamin D cutoff } \\
25 \mathrm{ng} / \mathrm{mL} .\end{array}$ & & $\begin{array}{c}\text { cGVHD at } 2 \mathrm{y}: \\
63.8 \% \text { vs. } 23.8 \%(\mathrm{p}=0.009) \\
\text { Extensive cGVHD at } 2 \mathrm{y}: \\
54.5 \% \text { vs. } 14.3 \%(\mathrm{p}=0.005)\end{array}$ & $\begin{array}{l}\text { OS: } 53 \% \text { vs. } 50 \%(\mathrm{P}=0.57) \\
\text { PFS: } 51 \% \text { vs. } 47 \%(\mathrm{P}=0.61) .\end{array}$ \\
\hline $\begin{array}{c}\text { Campos } \\
\text { et al, 2014 } \\
{[169]}\end{array}$ & Prospective & 66 & $\begin{array}{l}25.7 \pm 12.3 \mathrm{ng} / \mathrm{mL} \text { vs. } \\
\text { controls } 31.9(\mathrm{P}=0.01) \\
\text { Deficiency prevalence } \\
(32 \% \text { vs } 8 \% ; \mathrm{p}=0.01)\end{array}$ & $\begin{array}{c}\mathrm{D}+30: 22.7 \pm 10.7 \mathrm{ng} / \mathrm{mL} \\
\mathrm{D}+180: 20.9 \pm 10.9 \mathrm{ng} / \mathrm{mL} \\
(\mathrm{p}=0.01)\end{array}$ & No association with GvHD. & No effect on survival. \\
\hline $\begin{array}{c}\text { Beebe } \\
\text { et al, 2018 } \\
{[170]}\end{array}$ & Retrospective & 72 & $\begin{array}{c}26 \mathrm{ng} / \mathrm{mL} \\
(19-34 \mathrm{ng} / \mathrm{mL}) \\
\text { Deficiency: } 35 \%\end{array}$ & $\begin{array}{l}\text { Pre-HSCT and } \mathrm{D}+100, \\
\text { similar, at } 1 \text { year }(\mathrm{p}=0,01) \text { : } \\
\quad 35 \pm 16 \text { vs. } 27 \pm 10\end{array}$ & No association with GvHD. & $\begin{array}{l}\text { 1-year OS significantly lower } \\
\text { among patients with vitamin } \mathrm{D} \\
\text { deficit }(\mathrm{P}=0.001) \text {. }\end{array}$ \\
\hline $\begin{array}{l}\text { Urbain, } \\
\text { et al, 2012 } \\
{[160]}\end{array}$ & Prospective & 102 & $\begin{array}{c}16.4 \pm 8.9 \mathrm{ng} / \mathrm{mL} \\
89.2 \% \text { had }<30 \mathrm{ng} / \mathrm{mL} \\
\text { and } 23.5 \%<10 \mathrm{ng} / \mathrm{mL}\end{array}$ & $\begin{array}{l}\mathrm{D}+30: 15.5 \pm 8.7 \mathrm{ng} / \mathrm{mL} \\
\mathrm{D}+100: 14.9 \pm 7.5 \mathrm{ng} / \mathrm{mL}\end{array}$ & $\begin{array}{l}\text { Trend towards higher risk of grade } \\
2-4 \text { aGvHD among patients with } \\
\text { lower vitamin D levels }(\mathrm{P}=0.066) \text {. }\end{array}$ & \\
\hline $\begin{array}{c}\text { Gjærde, } \\
\text { et al, 2021 } \\
{[186]}\end{array}$ & Retrospective & 116 & $\begin{array}{c}64 \mathrm{nmol} / \mathrm{L} . \\
29 \% \mathrm{had}<50 \mathrm{nmol} / \mathrm{L} \text { and } \\
8 \%<25 \mathrm{nmol} / \mathrm{L} .\end{array}$ & & $\begin{array}{c}\text { Pre-HSCT }>85 \mathrm{nmol} / \mathrm{L} \text { had } 1.5 \text { times } \\
\text { higher odds of grade II-IV aGvHD } \\
\text { than }<47 \mathrm{nmol} / \mathrm{L}(\mathrm{CI}: 0.84-2.7)\end{array}$ & \\
\hline $\begin{array}{c}\text { Bajwa } \\
\text { et al, 2021 } \\
{[172]}\end{array}$ & Retrospective & 233 & $\begin{array}{l}24.24 \mathrm{ng} / \mathrm{mL} . \\
\text { All patients had vitamin } \\
\text { D insufficiency. }\end{array}$ & $\begin{array}{l}\mathrm{D}+3024.76 \mathrm{ng} / \mathrm{mL} \text { vs. } \\
\mathrm{D}+10029.89 \mathrm{ng} / \mathrm{mL} \\
\text { All normal thereafter. }\end{array}$ & $\begin{array}{l}\text { No statistical difference in acute or } \\
\text { chronic GvHD. }\end{array}$ & No significant influence on OS. \\
\hline $\begin{array}{c}\text { Hansson } \\
\text { et al, 2014 } \\
{[167]}\end{array}$ & Retrospective & 123 & $\begin{array}{l}\text { Insufficient level group } \\
33 \mathrm{nmol} / \mathrm{L}(13-49) \\
\text { Sufficient level group }\end{array}$ & $\begin{array}{l}\text { Vitamin D at } 6 \text { months: } \\
23 \mathrm{nmol} / \mathrm{L}(18-24) \text { in } \\
\text { moderate / severe cGVHD }\end{array}$ & $\begin{array}{l}\text { Grades } 2-4 \text { aGvHD: } \\
-47 \% \text { in Low vitamin } \mathrm{D} \text { levels vs } \\
-30 \% \text { in the sufficient }(\mathrm{P}=0.05) .\end{array}$ & $\begin{array}{l}\text { OS: } 87 \% \text { vs. } 50 \%, p=0.01 \text { for } \\
\text { insufficient vs sufficient level } \\
\text { Relapse for insufficient vs. }\end{array}$ \\
\hline
\end{tabular}




\begin{tabular}{|c|c|c|c|c|c|c|}
\hline & & & $63 \mathrm{nmol} / \mathrm{L}(50-97)$ & $\begin{array}{l}\text { vs } 37 \mathrm{nmol} / \mathrm{L}(10-80) \text { in } \\
\text { no cGVHD }(\mathrm{p}=0.004)\end{array}$ & & $\begin{array}{l}\text { sufficient level groups: } \\
33 \% \text { vs. } 4 \%, p=0.03 \text {. }\end{array}$ \\
\hline $\begin{array}{c}\text { Von Bahr } \\
\text { et al, 2015 } \\
{[168]}\end{array}$ & Retrospective & 166 & $\begin{array}{c}42 \mathrm{nmol} / \mathrm{L}(10-118) \\
(53 \% \text { insufficient levels, } \\
11 \% \text { deficient }) \\
\text { Healthy controls: } \\
66.5 \text { nmol/L }(21-104) \\
(\mathrm{p}<0.001) .\end{array}$ & $\begin{array}{c}39 \mathrm{nmol} / \mathrm{L}(10-116) \text {, at } 6 \\
\text { months. }\end{array}$ & $\begin{array}{l}\text { No significant impact on aGvHD. } \\
\text { 2-year cGvHD (moderate/severe): } \\
\text { Deficient vit. D level: } 56 \% \\
\text { Insufficient vit. D level: } 31 \% \\
\text { Sufficient vit. D levels: } 21 \% \\
(p=0.01) .\end{array}$ & $\begin{array}{l}\text { 2-y OS according vit. D levels: } \\
\text { Deficient } 63 \% \text {, Insufficient } 69 \% \\
\text { Normal } 76 \% ; \mathrm{p}=0,24 \text {; aa } \mathrm{p}=0.02 \\
\text { Significant } \uparrow \text { of CMV disease if } \\
\text { deficient vit. } \mathrm{D}(\mathrm{p}=0.005) \\
\text { and } \uparrow \text { antibiotics }(\mathrm{p}=0.011)\end{array}$ \\
\hline $\begin{array}{c}\text { Katic } \\
\text { et al, 2016 } \\
{[173]}\end{array}$ & Prospective & 310 & & $\begin{array}{l}\text { Only patients with GvHD. } \\
30 \mathrm{ng} / \mathrm{mL}(22-42) \text {. } \\
77.7 \% \mathrm{had}>20 \mathrm{ng} / \mathrm{mL} \text { and } \\
22.3 \% \mathrm{had} \leq 20 \mathrm{ng} / \mathrm{mL} \text {. }\end{array}$ & $\begin{array}{l}\text { No association between vit. D levels } \\
\text { and major cGvHD characteristics. }\end{array}$ & $\begin{array}{l}\downarrow \text { OS in patients with vitamin D } \\
\leq 20 \mathrm{ng} / \mathrm{mL} \text { vs }>20 \mathrm{ng} / \mathrm{mL} .\end{array}$ \\
\hline $\begin{array}{c}\text { Perera } \\
\text { et al, 2015 } \\
{[175]}\end{array}$ & Retrospective & 492 & & & $\begin{array}{l}\text { No significant differences in } \\
\text { acute/chronic GVHD. }\end{array}$ & $\begin{array}{l}\text { Higher mortality in vitamin D } \\
\text { deficient cohort vs replete group } \\
\text { (HR } 1.5, \text { CI } 1.1-2.0, \mathrm{P}=0.013 \text { ). } \\
\text { No PFS or relapse differences }\end{array}$ \\
\hline $\begin{array}{c}\text { Peter } \\
\text { et al, 2021 } \\
{[177]}\end{array}$ & Prospective & $\begin{array}{c}143+ \\
365\end{array}$ & $\begin{array}{l}\text { All patients tested for } \\
\text { 1,25-dihydroxyvitamin-D3 } \\
\text { and } 25 \text {-hydroxyvitamin-D3 } \\
\text { at day - } 16 \text { to }-6 \text { before } \\
\text { allo-HSCT. } \\
\end{array}$ & $\begin{array}{c}\text { 25-hydroxyvitamin-D3 } \\
\text { showed a steady increase, } \\
\text { 1,25-dihydroxyvitamin-D3 } \\
\text { peaked around the time of } \\
\text { allo-HSCT. }\end{array}$ & $\begin{array}{l}\text { No significant association between } \\
\text { vitamin D levels and severe GvHD. }\end{array}$ & $\begin{array}{l}\downarrow 25 \text {-hydroxyvitamin-D3 during } \\
\text { follow up or } \downarrow \text { peritransplant } \\
\text { 1,25-dihydroxyvitamin-D3 were } \\
\text { associated with increased TRM } \\
\quad(p=0.002 \text { and } p=0.001) .\end{array}$ \\
\hline
\end{tabular}

aa: age adjusted

Table 3: Interventional studies evaluating the administration of vit $\mathrm{D}$ after allogeneic transplantation. 


\begin{tabular}{|c|c|c|c|c|c|c|}
\hline & & & and dose & Pre-Allo & Post-Allo & NRM and Survival \\
\hline $\begin{array}{c}\text { Silva } \\
\text { et al, 2011 } \\
{[181]}\end{array}$ & $\begin{array}{c}\text { Retrospective } \\
/\end{array}$ & 12 & $\begin{array}{l}\text { Cholecalciferol } 1000 \text { IU per day } \\
\text { (oral) plus calcium carbonate } \\
1250 \mathrm{mg} \text { (one pill per daily) af- } \\
\text { ter HSCT for at least } 6 \text { months } \\
\text { in patients with osteopenia }\end{array}$ & & & $\begin{array}{c}\text { All patients had active cGvHD. } \\
\text { At } 6 \text { months after treatment: } \\
-5 \text { patients obtained complete response } \\
\text { - } 6 \text { patients obtained partial response } \\
\text { - } 1 \text { patient had no response. }\end{array}$ \\
\hline $\begin{array}{c}\text { Duncan } \\
\text { et al, 2011 } \\
{[188]}\end{array}$ & Prospective / & 22 & $\begin{array}{l}\text { Ergocalciferol: 50,000 IU } \\
\text { once weekly for } 6 \text { weeks }\end{array}$ & $\begin{array}{l}\text { Mean pre-transplantation } \\
22.8 \mathrm{ng} / \mathrm{mL} \text { (7-42.6). } \\
\text { Vitamin D deficiency: } \\
37.3 \% \text { (CI } 25.8 \%-50 \%) .\end{array}$ & $\begin{array}{l}\text { Mean increase following } \\
\text { supplementation: } \\
18.8(\mathrm{SD}=11.3,8-42) \\
4.5 \% \text { remained deficient }\end{array}$ & \\
\hline $\begin{array}{c}\text { Bhandari } \\
\text { et al, 2021 } \\
{[182]}\end{array}$ & $\begin{array}{l}\text { Prospective / } \\
\text { (historical } \\
\text { cohort } \\
\text { comparison) }\end{array}$ & 33 & $\begin{array}{l}\text { Cholecalciferol: one-time oral } \\
\text { Stoss* dose of cholecalciferol in } \\
5000 \mathrm{IU} / \mathrm{mL} \text { liquid formulation, } \\
5000 \mathrm{IU} / \mathrm{capsule} \text {, or } 50,000 \\
\mathrm{IU} / \text { capsule vs standard dose } \\
14 \text { days before conditioning. }\end{array}$ & $\begin{array}{l}\text { Mean pre-transplantation } \\
27.7 \mathrm{ng} / \mathrm{mL} \text { (SD 10.8). } \\
\\
59 \% \text { were vitamin D in- } \\
\text { sufficient vs. } 61 \% \text { in the } \\
\text { historical cohort. }\end{array}$ & $\begin{array}{l}* \text { Mean level }(\mathrm{p}<0.001) \\
\text { post Stoss: } 72.2 \mathrm{ng} / \mathrm{mL} \text { vs. } \\
\text { standard dose: } 35.8 \mathrm{ng} / \mathrm{mL} \\
* \text { Vitamin D sufficiency in } \\
97 \% \text { of Stoss cohort } \\
\text { vs. } 67 \% \text { of standard dose }\end{array}$ & $\begin{array}{l}\text { No association with acute GvHD, veno- } \\
\text { oclusive disease or transplant associated } \\
\text { thrombotic microangiopathy. }\end{array}$ \\
\hline $\begin{array}{c}\text { Kenny } \\
\text { et al, 2019 } \\
{[155]}\end{array}$ & Prospective / & 144 & $\begin{array}{l}\text { Cholecalciferol: The dose was } \\
\text { guided by vitamin D levels } \\
\text { (max. } 50000 \text { IU orally once } \\
\text { weekly). }\end{array}$ & $\begin{array}{l}72.9 \% \text { were vitamin D } \\
\text { deficient before HSCT. } \\
\text { Mean pre-transplantation } \\
21 \mathrm{ng} / \mathrm{mL} \text {. }\end{array}$ & $\begin{array}{l}\text { 26.4\% were vitamin D defi- } \\
\text { cient before HSCT. } \\
\text { Mean 6-month posttrans- } \\
\text { plant level: } 36 \mathrm{ng} / \mathrm{mL} \text {. }\end{array}$ & \\
\hline $\begin{array}{l}\text { Caballero- } \\
\text { Velázquez }\end{array}$ & Prospective / & 150 & $\begin{array}{l}\text { 1,25-Dihydroxyvitamin D3. } \\
\text { 3 groups: }\end{array}$ & $\begin{array}{l}\text { Plasma levels of } \\
\text { 25-OH vitamin D3 }\end{array}$ & $\begin{array}{l}\text { Significantly higher levels } \\
\text { among patients receiving }\end{array}$ & $\begin{array}{c}\downarrow \text { overall and moderate }+ \text { severe cGvHD } \\
\text { at } 1 \text { year: } \operatorname{LdD}(37.5 \% \text { and } 19.5 \%)\end{array}$ \\
\hline
\end{tabular}




\begin{tabular}{cccc}
\hline et al, 2016 & Control group $(\mathrm{CG}):$ no vitamin & were measured on days & high doses as compared with \\
{$[184]$} & Low-dose $(\mathrm{LdD}): 1,000 \mathrm{IU} /$ day, & $-5,+1,+7,+14$ and +21. & the control group beyond \\
& High-dose $(\mathrm{HdD}): 5,000 \mathrm{IU} /$ day & day +7.
\end{tabular}

HdD (42.4\% and 27\%) compared with CG $(67.5 \%$ and $44.7 \%$; $\mathrm{P}<0.05)$

In multivariable analysis, vitamin D $\downarrow$ the risk of overall cGvHD and moderate + severe cGvHD $(\mathrm{p} \leq 0.01)$ Similar relapse rate and survival.

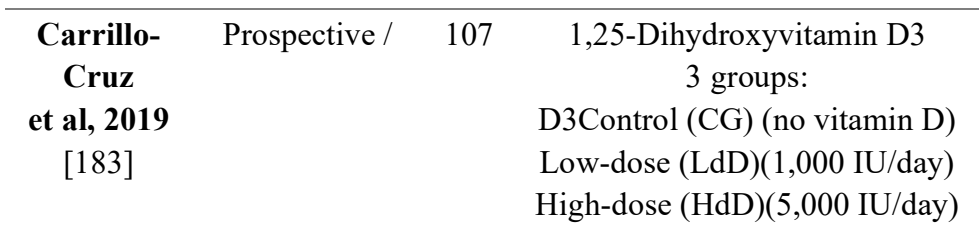

The incidence of overall cGvHD varied depending on the VDR genotype: among patients with FokI CT genotype (22.5\% vs $80 \%, \mathrm{P}=0.0004)$ and among patients treated with vitamin $\mathrm{D}$ as compared with the CG (HR 0.143, P < 0.001).

Patients w/o BsmI/ApaI/TaqI ATC haplotype $(22.2 \%$ vs. $68.8 \%, \mathrm{P}=0.0005)$.

\begin{tabular}{|c|c|c|c|c|c|}
\hline $\begin{array}{c}\text { Bhandari, } \\
\mathbf{2 0 2 0} \\
{[182]}\end{array}$ & Prospective / & 314 & Cholecalciferol & $\begin{array}{l}\text { Obtained in } 94 \text { patients. } \\
\text { Mean levels of vitamin D } \\
\text { with supplementation } \\
33.67 \mathrm{ng} / \mathrm{mL} \\
\text { vs. } 29.16 \mathrm{ng} / \mathrm{mL} \\
\text { without it }(\mathrm{p}=0.11)\end{array}$ & $\begin{array}{c}31.85 \mathrm{ng} / \mathrm{mL} \text { in patients with } \\
\text { aGVHD } \\
\text { vs. } 31.42 \mathrm{ng} / \mathrm{mL} \text { in those } \\
\text { w/o aGVHD }(\mathrm{p}=0.91) .\end{array}$ \\
\hline
\end{tabular}

Vitamin D levels did correlate with OS: every $10 \mathrm{ng} / \mathrm{mL}$ increase there was a $28 \%$ decreased risk of death $(\mathrm{P}=0.01)$. No difference for levels before HSCT.

Malignant diagnosis was associated (multivar. analysis) with EFS ( $\mathrm{P}<0.01)$.

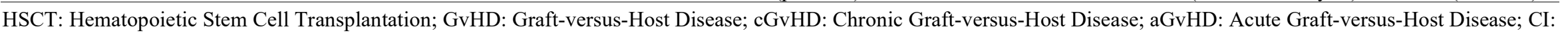

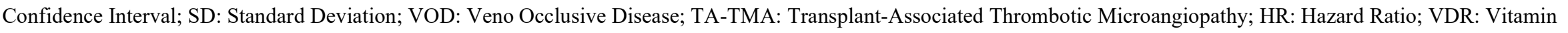
D Receptor; SNPs: Single Nucleotide Polymorphisms; OS: Overall Survival.

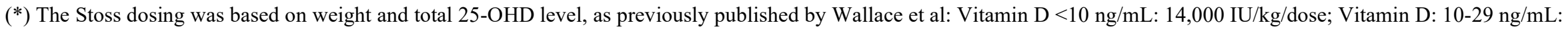
12,000 IU/kg/dose; Vitamin D 30-50 ng/mL: $7000 \mathrm{IU} / \mathrm{kg} / \mathrm{dose}$.

$(\wedge)$ National Kidney Foundation.

If with an aggressive dosage increase in those who remained vitamin D insufficient. 
Table 4. Clinical trials currently active evaluating the use of vitamin D among patients undergoing allo-HSCT.

\begin{tabular}{|c|c|c|c|c|}
\hline & $\mathbf{N}$ & Vitamin D & Dose & Main Objective \\
\hline $\begin{array}{l}\text { Children's Hospital } \\
\text { Medical Center, } \\
\text { Cincinnati, } 2018\end{array}$ & 100 & & $\begin{array}{l}\text { Single large dose of vita- } \\
\text { min D "stoss therapy" with } \\
\text { a placebo vs. single large } \\
\text { doses of both vitamins D } \\
\text { and A. }\end{array}$ & $\begin{array}{l}\text { Incidence of acute GI GvHD at } \\
\text { day }+100 \text { after transplant. }\end{array}$ \\
\hline $\begin{array}{l}\text { Children's Hospital } \\
\text { Medical Center, } \\
\text { Cincinnati, } 2021\end{array}$ & 20 & Cholecalciferol & $\begin{array}{l}\text { Vitamin D OTF weekly for } \\
\text { a maximum of } 12 \text { weeks. } \\
\text { The dose may be in- } \\
\text { creased or decreased } \\
\text { based on the dosing } \\
\text { schema. }\end{array}$ & $\begin{array}{l}\text { To investigate efficacy of OTF D3 } \\
\text { replacement by measuring vita- } \\
\text { min D levels. }\end{array}$ \\
\hline $\begin{array}{l}\text { Children's Hospital } \\
\text { Los Angeles, } 2018\end{array}$ & 33 & Cholecalciferol & $\begin{array}{l}\text { Single dose of ultra-high- } \\
\text { dose vitamin D. }\end{array}$ & $\begin{array}{l}\text { 1. Incidence of GvHD, veno-oc- } \\
\text { clusive disease and thrombotic } \\
\text { microangiopathy at day }+100 \text { af- } \\
\text { ter transplant. }\end{array}$ \\
\hline $\begin{array}{l}\text { Children's Hospital } \\
\text { Medical Center, } \\
\text { Cincinnati, } 2016\end{array}$ & 10 & Cholecalciferol & $\begin{array}{l}\text { One oral vitamin D dose } \\
\text { (based on vitamin D status } \\
\text { and rounded to } 5000 \mathrm{IU} \text { ) } \\
<2 \text { weeks prior to HSCT. }\end{array}$ & $\begin{array}{l}\text { 2. Vitamin D sufficiency } \\
\text { following Stoss dosing, } \\
\text { prior to transplant. }\end{array}$ \\
\hline $\begin{array}{l}\text { University of Brit- } \\
\text { ish Columbia, } 2018\end{array}$ & 84 & Cholecalciferol & $\begin{array}{c}\text { Intervention group: } \\
\text { loading dose of } 100000 \mathrm{IU} \\
\text { vitamin D3, after } \\
\text { vitamin D3 } 2000 \text { IU daily. }\end{array}$ & $\begin{array}{l}\text { To test the efficacy and safety of } \\
\text { high dose vitamin D therapy by } \\
\text { measuring serum } 25-\mathrm{OH} \text { vitamin } \\
\text { D level weekly for } 8 \text { weeks. }\end{array}$ \\
\hline $\begin{array}{l}\text { Seoul National } \\
\text { University Hospi- } \\
\text { tal, } 2017\end{array}$ & 88 & Cholecalciferol & $\begin{array}{l}\text { Control group: } 2000 \mathrm{IU} \\
\text { vitamin D3 daily. }\end{array}$ & $\begin{array}{l}\text { Assess the efficacy (patients } \\
\text { achieving sufficient serum } 25-\mathrm{OH} \\
\text { vitamin D3 level in day }+100 \\
\text { post-aHSCT) with } 100.000 \mathrm{IU} \\
\text { vitamin D3 prior to aHSCT. }\end{array}$ \\
\hline
\end{tabular}

GI: Gastrointestinal; GvHD: Graft-versus-Host Disease; OTF: Oral Thun Film; HSCT: Hematopoietic Stem Cell Transplantation; 